Rese arch article

urn:1sid:zoobank.org:pub:5862FED7-135E-4648-93D4-46EEC294997A

\title{
Revision of the genus Ommatoiulus Latzel, 1884 (Julida, Diplopoda) in Portugal, with description of six new species
}

\author{
Nesrine AKKARI ${ }^{1, *}$ \& Henrik ENGHOFF ${ }^{2}$ \\ ${ }^{1}$ Naturhistorisches Museum Wien, Burgring 7, 1010 Wien, Austria. \\ ${ }^{2}$ Natural History Museum of Denmark, University of Copenhagen, \\ Universitetsparken 15, DK-2100 København Ø, Denmark. \\ ${ }^{*}$ Corresponding author: nesrine.akkari@nhm-wien.ac.at \\ ${ }^{2}$ Email: henghoff@snm.ku.dk \\ ${ }^{1}$ urn:1sid:zoobank.org:author:8DF67798-8E47-4286-8A79-C3A66B46A10F \\ ${ }^{2}$ urn:Isid:zoobank.org:author:FB09A817-000D-43C3-BCC4-2BC1E5373635
}

\begin{abstract}
In this work we present a revision of the genus Ommatoiulus Latzel, 1884 in Portugal. Based on recently collected material and older museum samples, including type specimens, we describe six new species to science, viz. Ommatoiulus alacygni sp. nov., O. camurus sp. nov., O. denticulatus sp. nov., $O$. litoralis sp. nov., $O$. staglae sp. nov. and $O$. stellaris sp. nov. The species $O$. alacygni sp. nov., $O$. denticulatus sp. nov. and $O$. staglae sp. nov. described from the Algarve are outstanding by their extremely reduced mesomerital process. The species $O$. porathi (Verhoeff, 1893) and O. andalusius (Attems, 1927) are recorded and redescribed for the first time after their original description. The finding of $O$. andalusius - originally described from Andalusia in Spain - constitutes a new record for Portugal together with two species, viz. O. fuentei (Brolemann, 1920) and O. martensi Mauriès, 1969. The taxonomic status of several species is revised. Thus Archiulus (Schistocoxitus) cingulatus Attems, 1927 is here considered as a junior synonym of Ommatoiulus lusitanus (Verhoeff, 1895) while Schizophyllum cervinum Verhoeff, 1910 is synonymized with Ommatoiulus moreleti (Lucas, 1860). An identification key to all hitherto known Portuguese species of Ommatoiulus is presented as well as a distribution map illustrating the various species occurrences in the country.
\end{abstract}

Keywords. Schizophyllini, Portugal, Ommatoiulus, new species, identification key.

Akkari N. \& Enghoff H. 2017. Revision of the genus Ommatoiulus Latzel, 1884 (Julida, Diplopoda) in Portugal, with description of six new species. European Journal of Taxonomy 295: 1-42. https://doi.org/10.5852/ ejt.2017.295

\section{Introduction}

With 76 described species from Europe and North Africa, the genus Ommatoiulus Latzel, 1884 is the most diverse of the tribe Schizophyllini, which also includes the monotypic genus Tachypodoiulus Verhoeff, 1893, and the 'genus' Rossiulus Attems, 1926 - the latter has never been formally elevated to a full genus though treated as such in recent literature (see Akkari \& Enghoff 2012). There are several 
subgeneric names in Ommatoiulus but these have long been considered as superfluous due to major discrepancies in their definition (see Akkari \& Enghoff 2012 and references therein). The species of Ommatoiulus in the Spanish region Andalusia have recently been a subject of a revision by Akkari \& Enghoff (2012) who recorded 19 species, ten of which new to science. The high proportion of new species - ca half of the total species known - in southern Spain is in line with the high species diversity in the Iberian Peninsula, one of the main Mediterranean biodiversity hotspots, in combination with the fact that the genus has not been subject to recent revisions in this area.

In the present work, we revise the genus Ommatoiulus in the southwest Iberian sector, Portugal; describe six new species to science and record further three species as new to Portugal. On the other hand, we revise the taxonomic status of several nominal species and propose new synonymies. Furthermore, we present an identification key based on gonopod structures to all hitherto known Ommatoiulus species of the area.

\section{Material and methods}

Specimens are preserved in 70\% alcohol. Measurements and photographs were made with a Nikon DSF2.5 camera mounted on a Nikon SMZ25 stereo microscope, using NIS-Elements Microscope Imaging Software with an Extended Depth of Focus (EDF) patch. Scanning electron microscopy (SEM) images are presented to illustrate the gonopods of some species. Samples prepared for SEM were dehydrated using $96 \%$ ethanol, followed by acetone, air-dried, mounted on aluminium stubs and coated with platinum. Images were taken using a JEOL JSM-6335F scanning electron microscope. All images were processed with Adobe Photoshop CS6 and assembled in Adobe InDesign CS6. The map was produced using Qgis 2.14. with GPS coordinates based on WGS 84 .

We use the same morphological terminology as Akkari \& Enghoff (2012).

\section{List of abbreviations used in the descriptions}

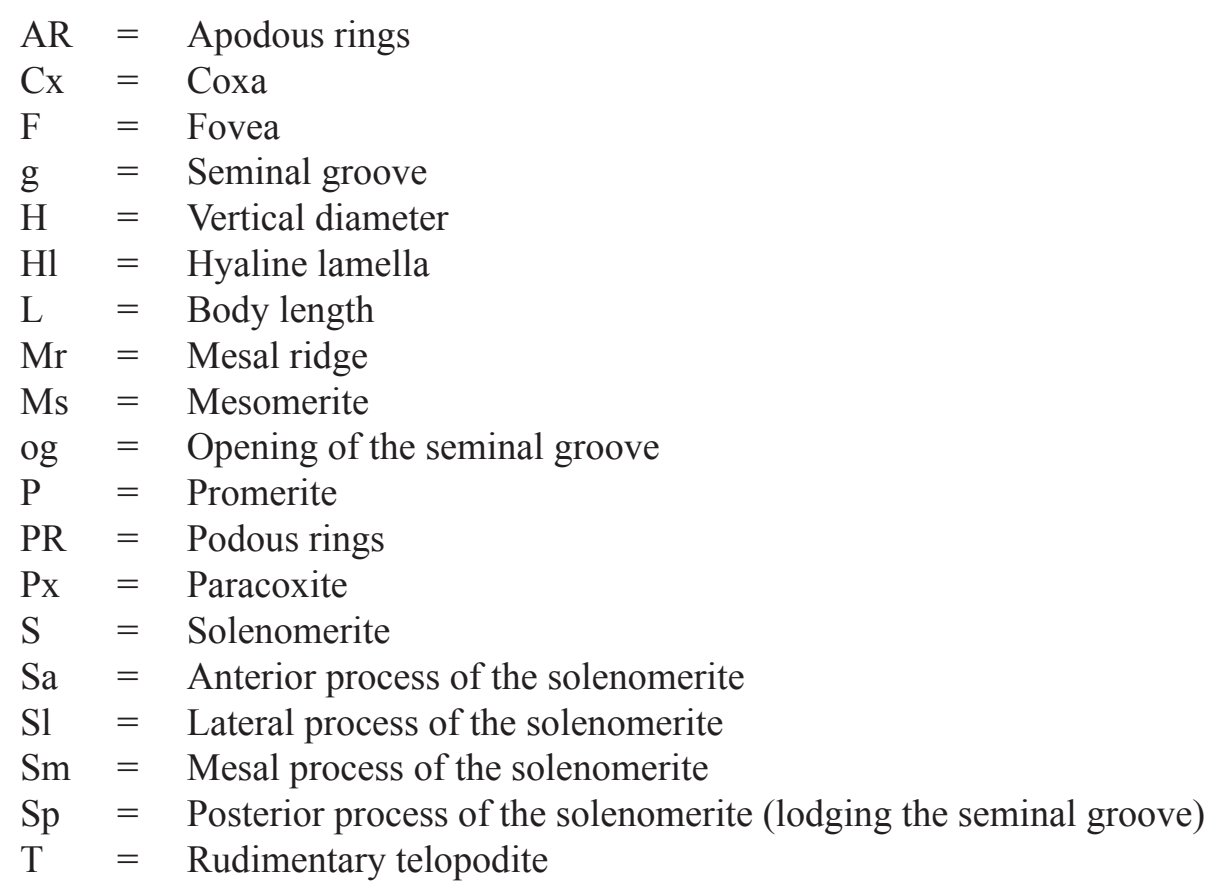

\section{Institutional abbreviations}

MCSNV $=$ Museo civico di Storia Naturale Verona 
MNCN $=$ Museo Nacional de Ciencias Naturales, Madrid

MNHN $=$ Muséum national d'Histoire naturelle, Paris

NHMW $=$ Naturhistorisches Museum Wien

SMNG = Senckenberg Museum für Naturkunde Görlitz

ZHM = Zoologisches Institut und Zoologisches Museum der Universität Hamburg

$\mathrm{ZMB}=$ Museum für Naturkunde, Zoological Museum Berlin

ZMUC = Natural History Museum of Denmark (Zoological Museum), University of Copenhagen

\section{Results}

Order Julida Brandt, 1833

Family Julidae Leach, 1814

Tribe Schizophyllini Verhoeff, 1909

Genus Ommatoiulus Latzel, 1884

Archiulus Berlese, 1886: 84, preoccupied.

Schizophyllum Verhoeff, 1895: 361.

Mesoiulus Verhoeff, 1893a: 480, preoccupied.

Palaioiulus Verhoeff, 1894: 150.

(See Hoffman (1980): 113 for a full list of subgenera/synonyms).

A genus of Julidae characterized by:

Lack of frontal setae.

Lack of a flagellum on the anterior gonopod.

Posterior gonopods consisting of a free mesomerite, a solenomerite, a strongly developed coxa with an often elaborate paracoxal process.

Solenomerite at base with a large, roundish, open fovea for storage of spermatozoa.

Ommatoiulus alacygni sp. nov.

urn:lsid:zoobank.org:act:11FBA7C7-2310-48BC-A33E-D469C97BFD3E

Figs 1-3

\section{Diagnosis}

Most similar to $O$. denticulatus sp. nov. and $O$. staglae sp. nov., agreeing with these in having a very reduced mesomerite and a complex multi-branched solenomerite; differing from both in the shape of the solenomerite and the jagged coxa resembling, in posterior view, a swan wing.

\section{Etymology}

The species epithet is a composite Latin noun meaning "swan wing" and refers to the shape of the gonopod coxa.

\section{Material examined}

\section{Holotype}

PORTUGAL: $1 \hat{\jmath}$, Faro District, Algarve, Ferragudo, 7 Mar. 1981, D. Kime leg. (ZMUC).

\section{Paratype}

PORTUGAL: 1 , same data as holotype. 


\section{Description}

Measurements. Male: $\mathrm{L}=35 \mathrm{~mm}, \mathrm{H}=3 \mathrm{~mm}, 45 \mathrm{PR}+1 \mathrm{AR}+$ Telson. Female: $\mathrm{L}=45 \mathrm{~mm}, \mathrm{H}=4.2 \mathrm{~mm}$, $46 \mathrm{PR}+2 \mathrm{AR}+\mathrm{Tel}$ son.

Colour. Faded after 35 years in alcohol (Fig. 1). Prozonites dark, greyish (perhaps originally deep brown); metazonites pale, almost whitish; dorsum with a thin black mid-dorsal line; legs pale brown to yellowish; head dark brown on the frontal part, paler towards the labral zone, mouthparts yellowish; preanal ring pale, anal valves blackish. Prozonites with oblique striae; metazonites with regular striation; suture complete, rectilinear but sometimes with a sinus at ozopore level. Anal valves with a marginal row of short setae, a submarginal row of longer ones, no setae (? broken) on disc. Subanal scale triangular, blunt and setose. Preanal ring with a protruding caudal projection bearing $2-3$ setae on tip, no hyaline process (?broken).

Gonopods (Figs 2-3). Promerite (P) stout, basally parallel-sided in posterior view, twice as long as broad with a rounded lateral margin, distally gradually narrowing and ending in a narrow apical tip; mesal ridge (Mr) fairly broad, ending in a blunt process at mid-length of the promerite; posterior surface with a small concavity near the mesal ridge (lodging the mesomerite); rudimentary telopodite $(\mathrm{T})$ small and located proximally near Mr (Fig. 3A). Posterior gonopod (Figs 2B-C, 3B-C): Mesomerite (Ms) reduced and very simple, less than half as long as the promerite; solenomerite (S) large, with an anterior long process (Sa) narrowing distad, apically tapering and bent posteriad, subapically bearing a triangular median hyaline lamella $(\mathrm{Hl})$; seminal groove $(\mathrm{g})$ running posteriorly from the fovea $(\mathrm{F})$ located at the base of the solenomerite along a posterior acuminate process ( $\mathrm{Sp}$ ) and opening in 'og'; the solenomerite shows another thin and long process pointing laterad (Sl). Paracoxite (Px) large, twisted antero-laterad

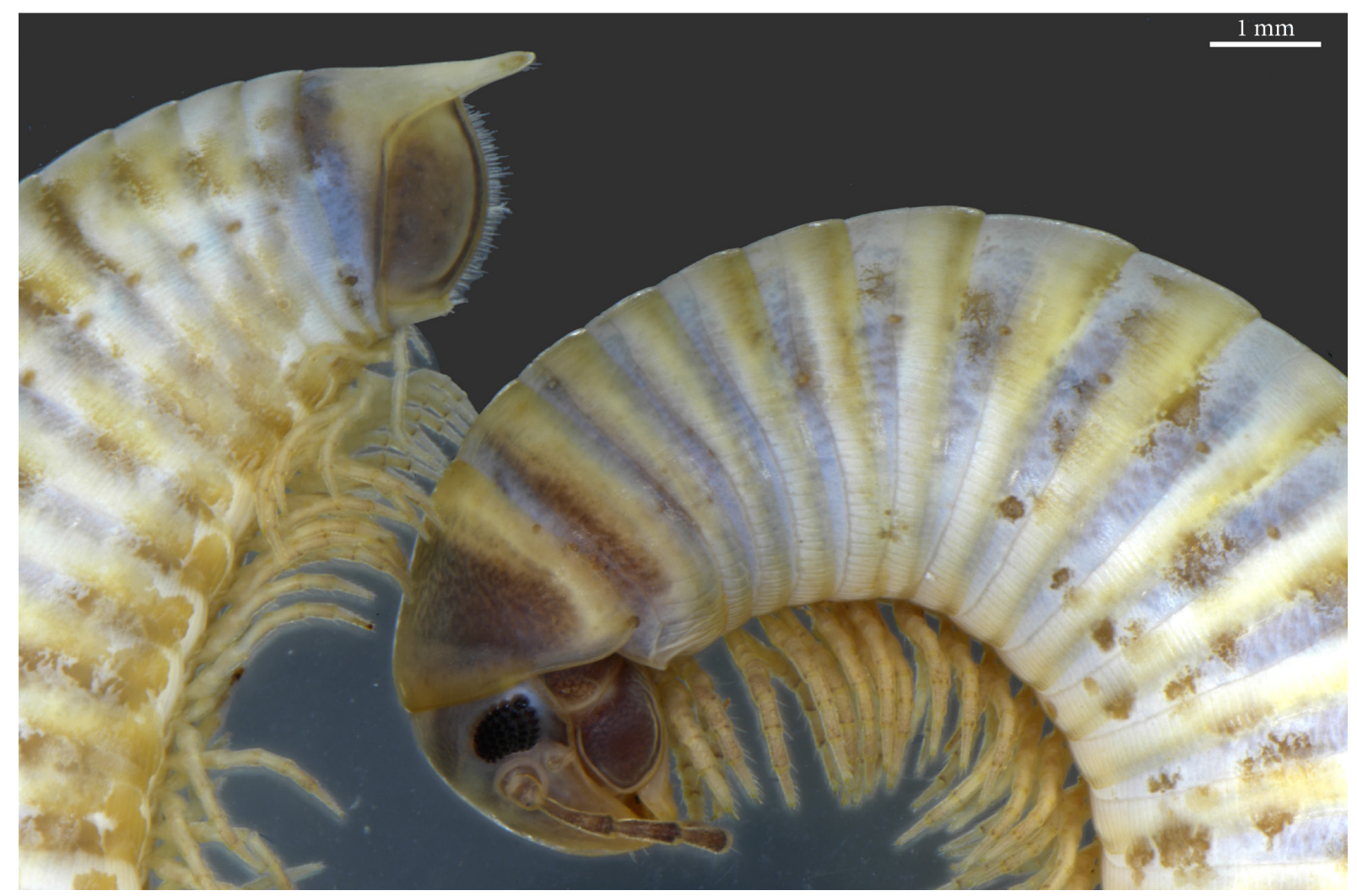

Fig. 1. Ommatoiulus alacygni sp. nov. Paratype + . habitus, lateral view. 
and extending beyond the rest of processes; distally abruptly expanding in a rounded bulge (Fig. $2 \mathrm{C}, \mathrm{E}$ ) then apically narrowing in a curved thin apex pointing anteriad; coxa $(\mathrm{Cx})$ very prominent, angular and characterised by the presence of a jagged margin with three protruding blunt processes, in lateral view reminding of the wing of a swan (Figs $2 \mathrm{C}, 3 \mathrm{C}$ ).
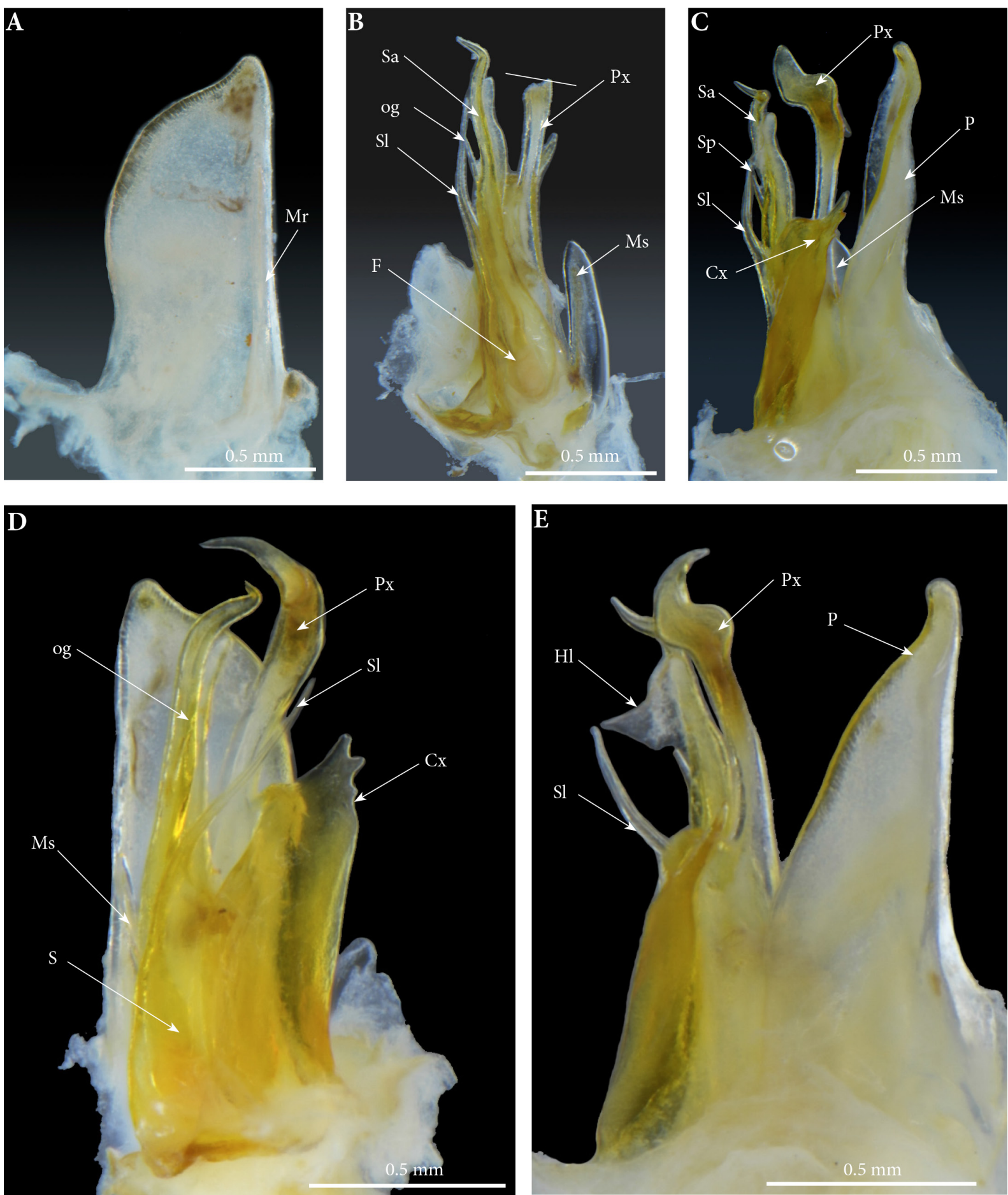

Fig. 2. Ommatoiulus alacygni sp. nov. Holotype $\hat{\delta}$, gonopods. A. Right promerite, posterior view. B. Right posterior gonopod, mesal view. Line marking the broken paracoxite. C. Left gonopod, lateral view. D. Left gonopod, meso-posterior gonopod. E. Left gonopod, antero-lateral view. 
A

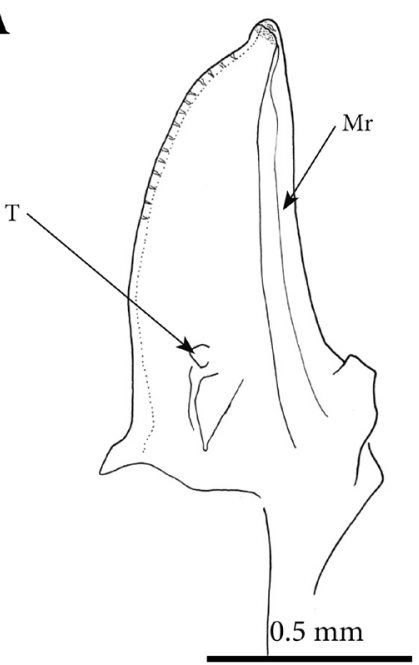

B

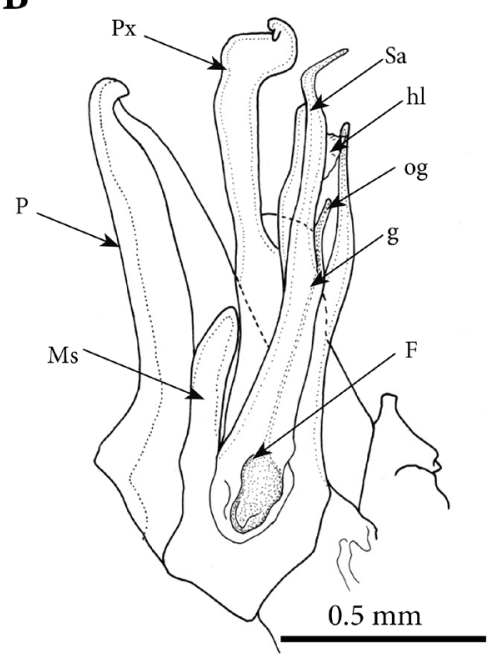

C

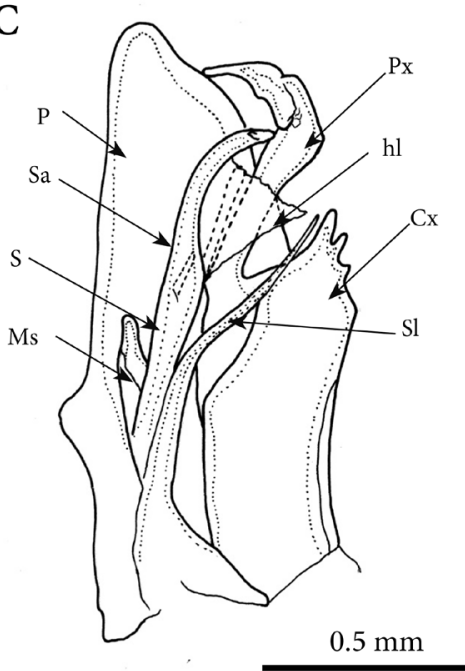

Fig. 3. Ommatoiulus alacygni sp. nov. Holotype $\hat{\jmath}$, gonopods. A. Right promerite, posterior view. B. Left gonopod, mesal view. C. Left gonopod, posterior view.

\section{Distribution}

South Portugal, Algarve, Ferragudo.

Ommatoiulus andalusius (Attems, 1927)

Fig. 4

Archiulus andalusius Attems, 1927: 282-283, figs 66-69.

Ommatoiulus andalusius - Mauriès 1978: 585. — Akkari \& Enghoff 2012: 5-6, figs 1-2.

\section{Material examined}

SPAIN: Archiulus andalusius holotype $\hat{\jmath}$, Andalusia, slide preparation, Latzel don., Peyl leg. (NHMW3164).

PORTUGAL: 1 đ , 4 우, 1 juvenile, Faro District, Aljezur, Pontal (Bordeira), Sandy Dunes, 37.19409 N, 8.91045 W, alt. 50 m, 12 Apr. 2005, P. Cardoso leg. (ZMUC).

\section{Descriptive notes}

A small species (Fig. 4A). Colour after 11 years in alcohol brownish, dorsum lighter with large middorsal spots, anal valves yellowish and setose, preanal ring with a short projection and an upturned hyaline tip, subanal scale triangular and setose. Male, broken in several parts, with $37 \mathrm{PR}+3 \mathrm{AR}+\mathrm{Telson}$, H $1.2 \mathrm{~mm}$, females 35-39 PR+1-2 AR+Telson, H 1.8-2.5 mm. The gonopods (Figs 4B-C) perfectly agree with the description of the type by Akkari \& Enghoff (2012).

\section{Distribution}

South Spain (Andalusia), Southwest Portugal (Aljezur). 


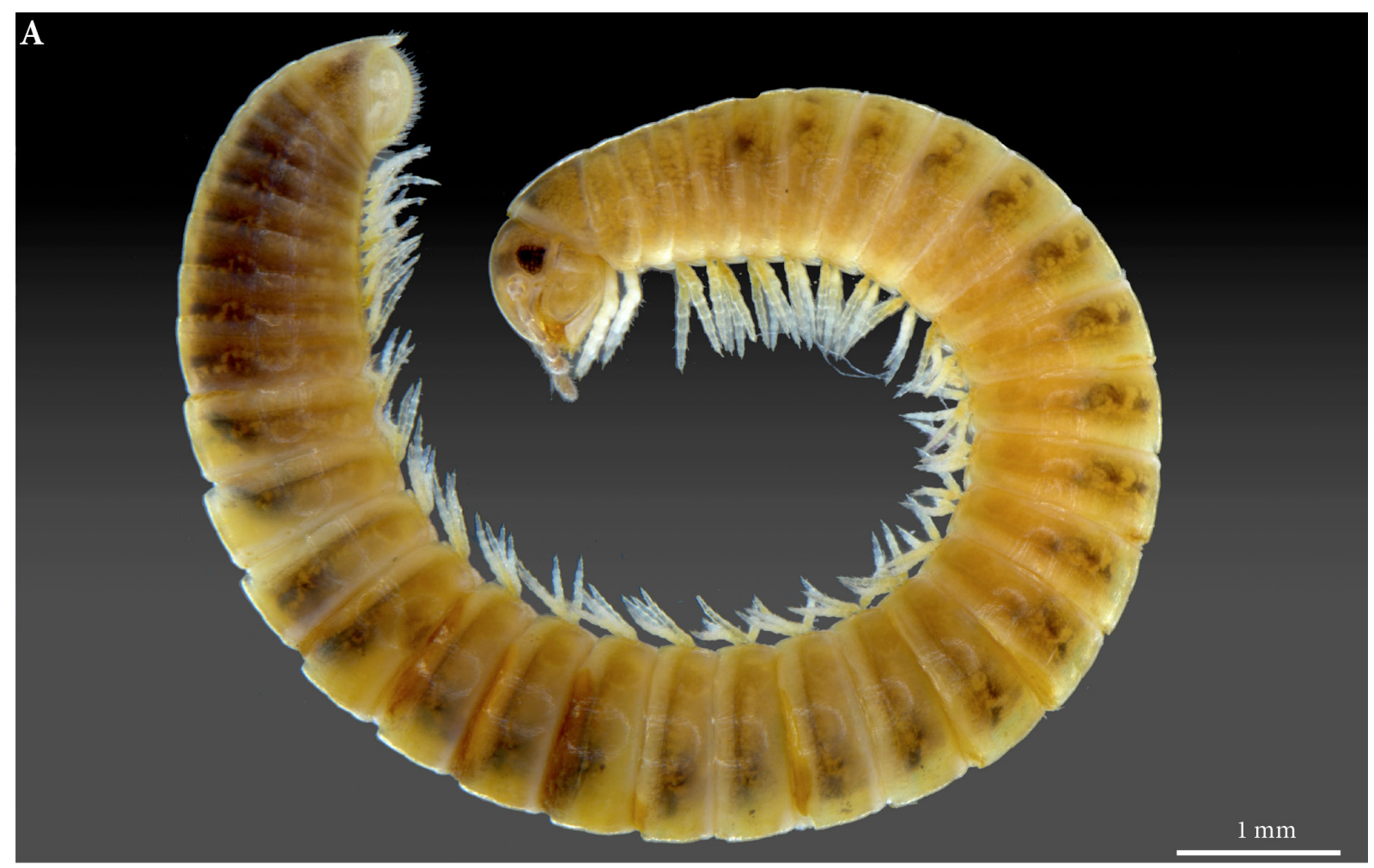

B
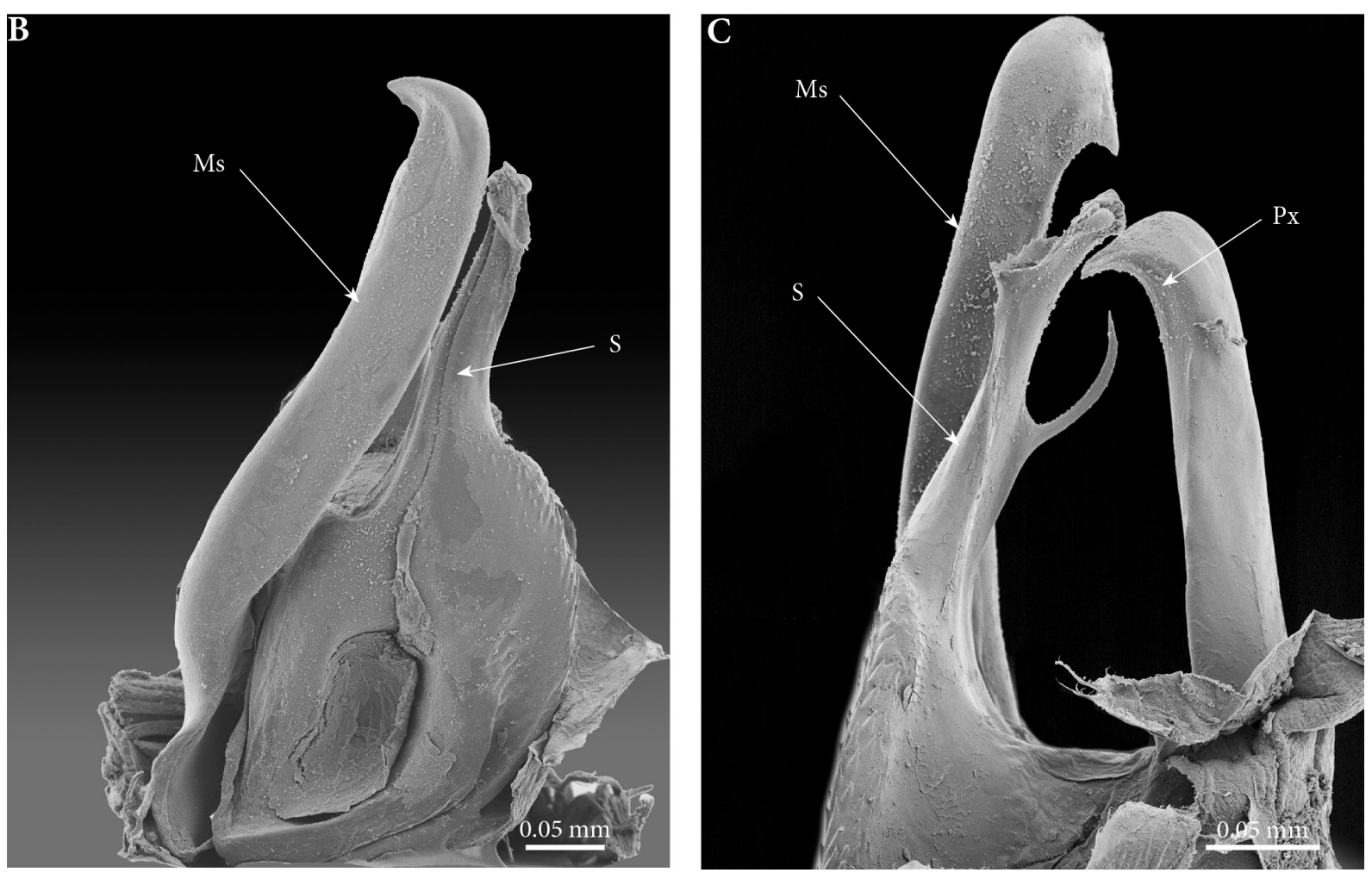

Fig. 4. Ommatoiulus andalusius (Attems, 1927), Aljezur, Portugal. A. ㅇ, habitus, lateral view. B. Male left posterior gonopod, mesal view. C. Male left posterior gonopod, posterior view. 


\section{Comments}

The species was hitherto only known from a slide preparation of the gonopods of the holotype (NHMW) collected at an unspecified locality in Andalusia. The specimens from Portugal represent the first record of the species after its initial description.

Ommatoiulus bipartitus (Verhoeff, 1910)

Fig. 5

Schizophyllum (Hemipodoiulus) bipartitum Verhoeff, 1910: 202-203, figs XIII, XIV, XX, XXIV.

Schizophyllum fissum Verhoeff, 1921: 76-77, figs 29-31. Synonymized by Mauriès \& Vicente 1977: 541. Schizophyllum involutum Verhoeff, 1925: 116, figs 36-38. Synonymized by Mauriès \& Vicente 1977: 541. Ommatoiulus moreleti subsp. Lienharti Brolemann, 1921: 182-184, figs 1, 5. Synonymized with involutum by Mauriès \& Vicente 1977: 543.

Schizophyllum (Hemipodoiulus) fissus - Machado 1953: 92.

Ommatoiulus lienhardti [sic!] - Mauriès 1971: 114.

Ommatoiulus bipartitus - Mauriès \& Vicente 1977: 541. — Vicente 1985: 321. — Akkari \& Enghoff 2012: 31 .

\section{Material examined}

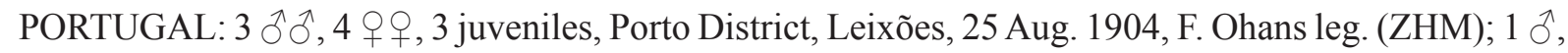
Porto District, Murgido, 41.220995 N, 7.937537 W, alt. 878, 24 Apr. 2012, M.G. París and N. Percino leg. (NHMW 8740).

\section{Distribution}

Northwest Portugal, North Spain, Southwest France.

\section{Comments}

Ommatoiulus bipartitus was described from Corunna (now: A Coruña) in NW Spain. All the Portuguese bipartitus specimens agree perfectly with Verhoeff's (1925) description of Schizophyllum involutum described from Portugal (Braga) and later synonymised with $O$. bipartitus (see Mauriès \& Vicente 1977, Vicente 1985). The similarities between the two nominal species are unquestionable; however, the consistency in the shape of the paracoxite in the Portuguese/Galician population is rather striking. It differs from the 'real' bipartitus in having more square than rounded and curved margins, exhibiting an apical fold and bearing additional processes/teeth (see Fig. 5B). The promerite of the 'involutus' morphotype is a little more voluminous with a notably more prominent lateral margin, a larger mesoapical process and without the mid-apical tooth. The 'involutus' morph seems to occur in western Iberian sector, being also identified from Galicia. Another nominal species of relevance here is Ommatoiulus lienharti described from the Arcachon in southwestern France (see Brolemann 1921) and later recorded in northern Spain. O. lienharti shows important similarities with both morphotypes mentioned above (Fig. 5C). Mauriès (1971) included $O$. lienharti in his list of millipedes from Cantabria and Spanish Pyrenees, being certain that the species must occur in the area. A few years later, Mauriès \& Vicente (1977) recorded O. lienharti from northern Portugal as a synonym of Schizophyllum involutum before synonymising the latter under $O$. bipartitus. In this work, we treat all these morphs as a single species under the oldest name, Ommatoiulus bipartitus, waiting for future detailed morphological/molecular analyses to help better delineating the nature of their phylogenetic relationships and clarifying their taxonomic status. 

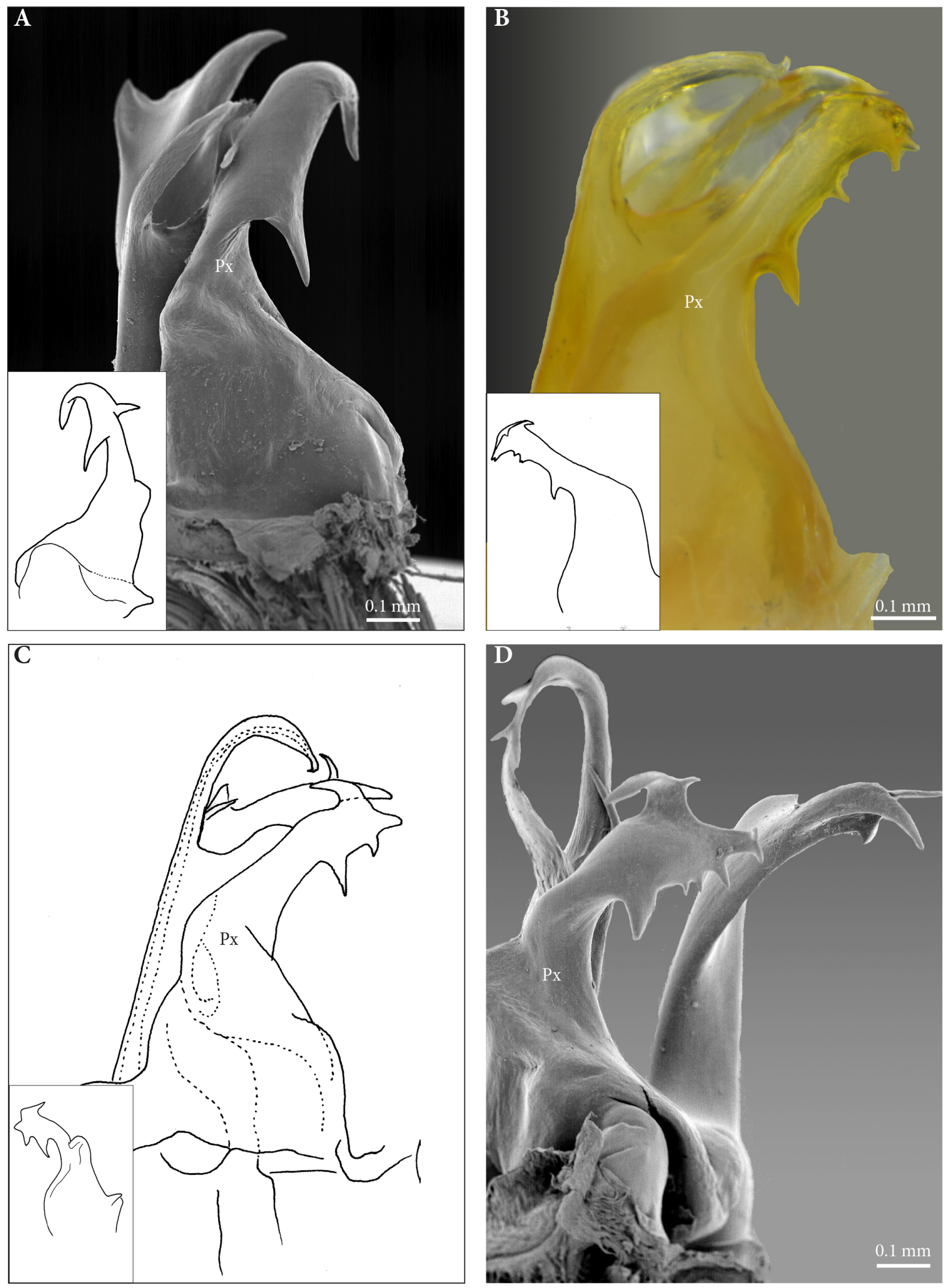

Fig. 5. Ommatoiulus bipartitus complex, paracoxite. Posterior view. A. bipartitus type, $ð$ from Leon. B. involutus type, $\widehat{\jmath}$ from A Coruña, Galicia. C. lienharti type, ô from Arcachon, redrawn from Brolemann (1921). D. Unspecified type, ô from the Basque Country. 


\section{Ommatoiulus camurus sp. nov. urn:1sid:zoobank.org:act:73D3CA71-7B9F-41B9-AA27-029C24F12E0D}

Figs $6-8$

\section{Diagnosis}

A large species. Most similar to O. armatus (Verhoeff, 1910) and O. dorsovittatus (Verhoeff, 1893), agreeing with these in the presence of a lateral notch on the promerite, a curved bifurcate mesomerite and a reduced paracoxite. Differing from both in the modified apex of the promerite, the deep curvature of the mesomerite and the shape of the solenomerite.

\section{Etymology}

The species epithet is a Latin adjective meaning curved and refers to the strongly curved shape of the posterior gonopods.

\section{Material examined}

\section{Holotype}

PORTUGAL: 1 §ૈ, Faro District, Algarve, Cape St. Vincent, 2 Mar. 1981, D. Kime leg. (ZMUC).

\section{Paratypes}

PORTUGAL: 2 + $q$, same data as holotype.

\section{Description}

Measurements. Male: $\mathrm{L}=45 \mathrm{~mm}, \mathrm{H}=5 \mathrm{~mm}, 45 \mathrm{PR}+2$ AR+Telson. Females: $\mathrm{L}=35-47 \mathrm{~mm}, \mathrm{H}=$ 4.5-6.1 mm, 41 PR+3 AR+Telson.

Colour. After 35 years in alcohol (Fig. 6). Prozonites uniformly light grey perhaps with faded marbling, metazonites anteriorly pale, dominated by a strong reddish brown colour with dense black sputter posteriorly and showing a striking yellow band on the posterior margin, a thin black mid-dorsal line; legs brownish; head dark brown, mouthparts lighter, antenna dark brown; telson and anal valves brownish. Prozonites with oblique striae; metazonites with regular striation; suture complete, rectilinear but sometimes with a sinus at ozopore level. Anal valves with a marginal row of short setae, a submarginal row of longer ones, disc glabrous (setae broken?); subanal scale triangular, clearly protruding and setose; preanal process broken on all specimens.
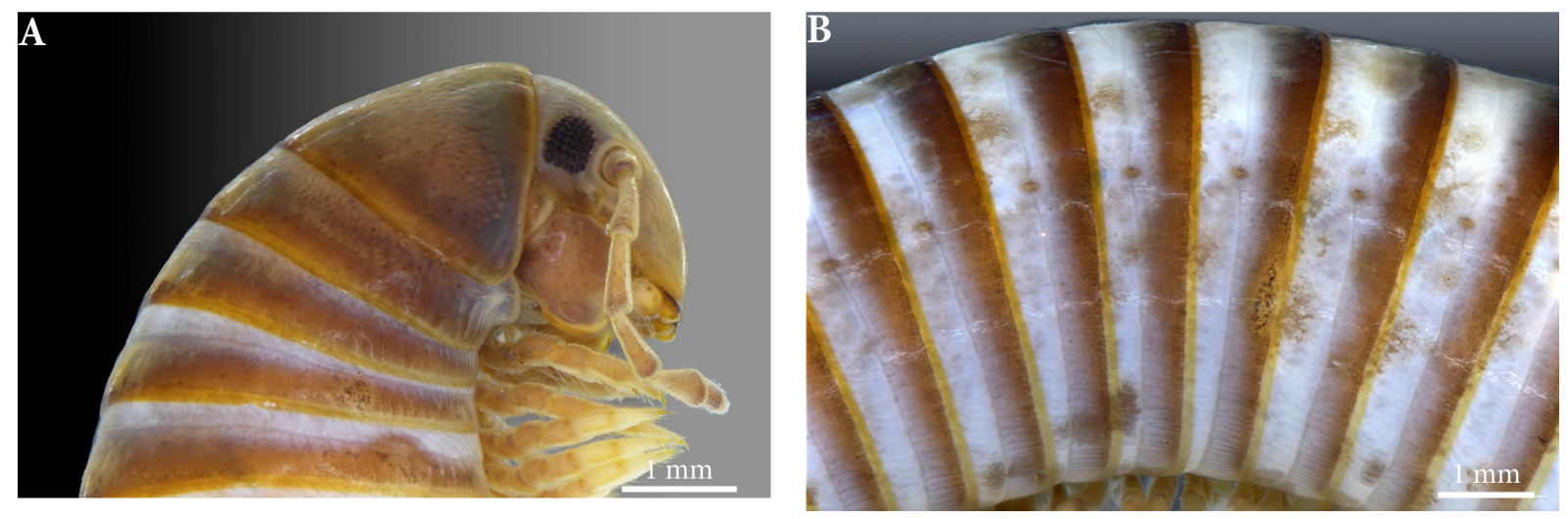

Fig. 6. Ommatoiulus camurus sp. nov. Holotype, $\widehat{\partial}$. A. Head and anteriormost body rings, lateral view. B. Mid-body rings, lateral view. 
Gonopods (Figs 7-8). Promerite (P) in posterior view broad at the base, gradually narrowing distad, lateral margin expanded and rounded, distally incised in a rounded notch; mesal ridge (Mr) broad and fusing with the mesal margin; promerite apex marked with a fold with a strongly sclerotized and serrated process on the mesal margin, and a subapical notch on the lateral one; rudimentary telopodite (T) small, located basally, close to the mesal ridge. Posterior gonopod: mesomerite (Ms) broad, hookshaped and strongly curved, distally bifurcating into two thin asymmetrical and downturned processes pointing meso-basad; solenomerite (S) much shorter than Ms, bearing strong serrations on the anterior and apical margin and fringed with a large number of spikes, and a thin acuminate mesal process ( $\mathrm{Sm})$ pointing distad; posterior process of the solenomerite ( $\mathrm{Sp}$ ) showing an acute tip lodging the opening of
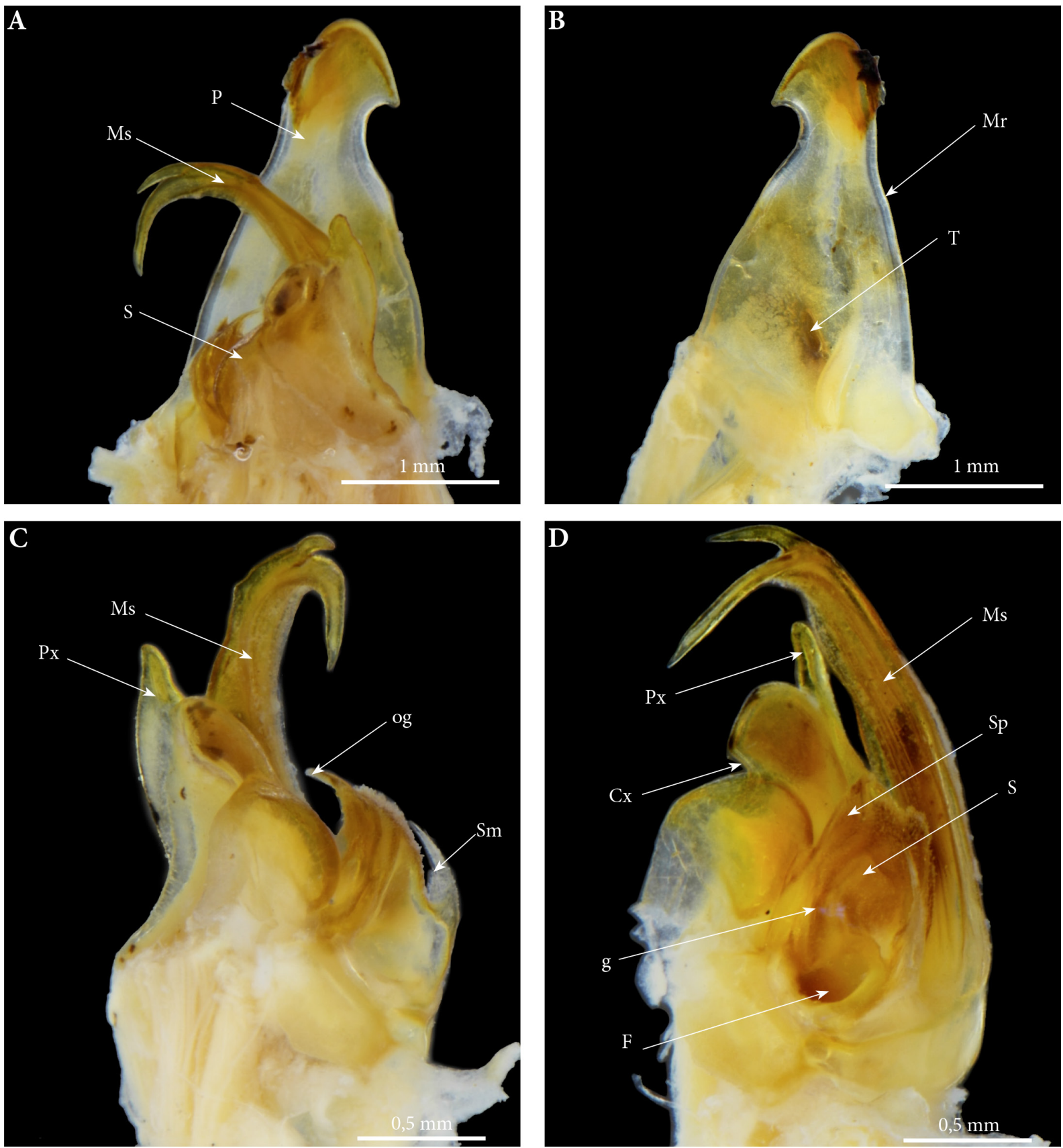

Fig. 7. Ommatoiulus camurus sp. nov. Holotype, ô. A. Left gonopod, posterior view. B. Right promerite, posterior view. C. Right posterior gonopod, lateral view. D. Left posterior gonopod, mesal view. 
the seminal groove 'og'; seminal groove (g) running posteriorly from the fovea (F) located at the base of the solenomerite up along Sp and opening in og (Figs 7D, 8B); paracoxite (Px) reduced, emerging from a bipartite round coxa $(\mathrm{Cx})$ (Figs $7 \mathrm{D}, 8 \mathrm{~B}-\mathrm{C})$.

\section{Distribution}

South Portugal, Algarve.

A

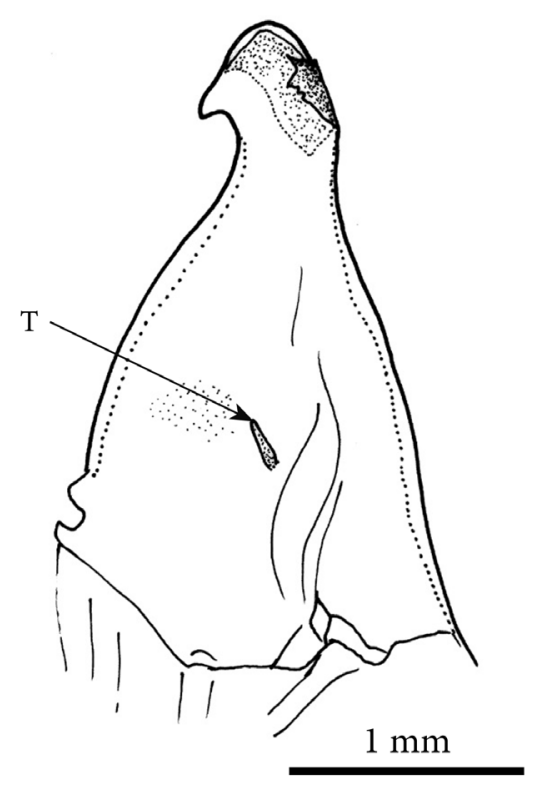

C

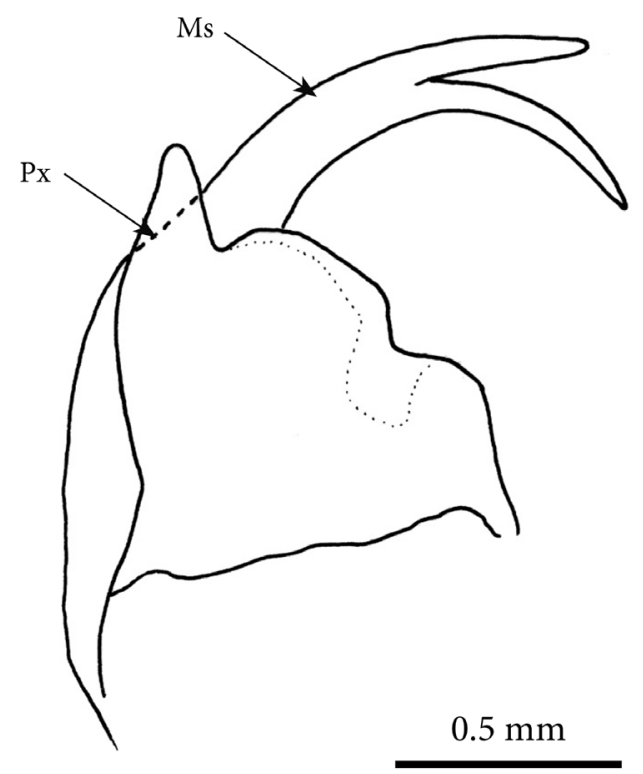

B

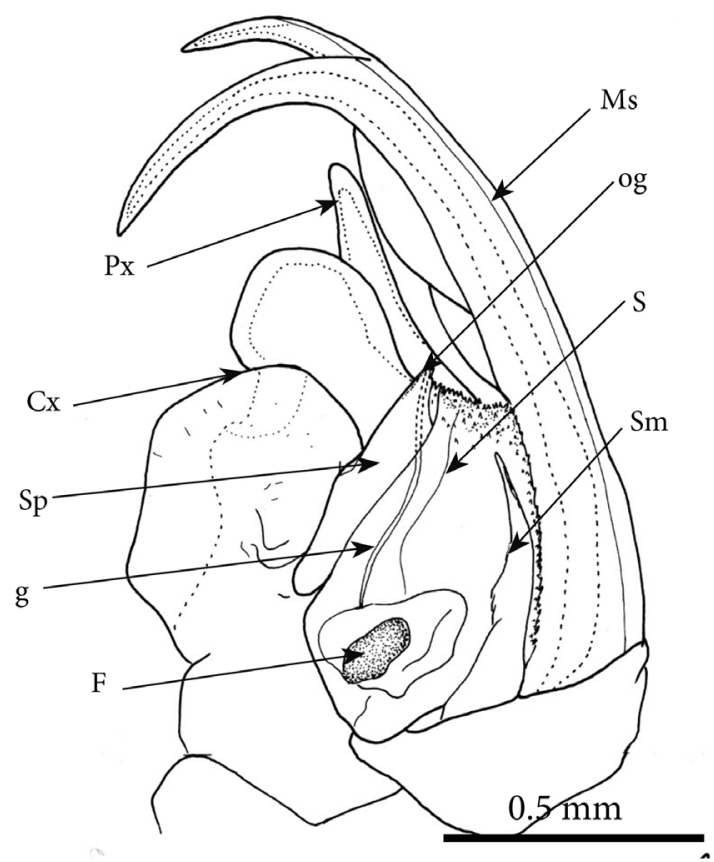

$\mathbf{D}$

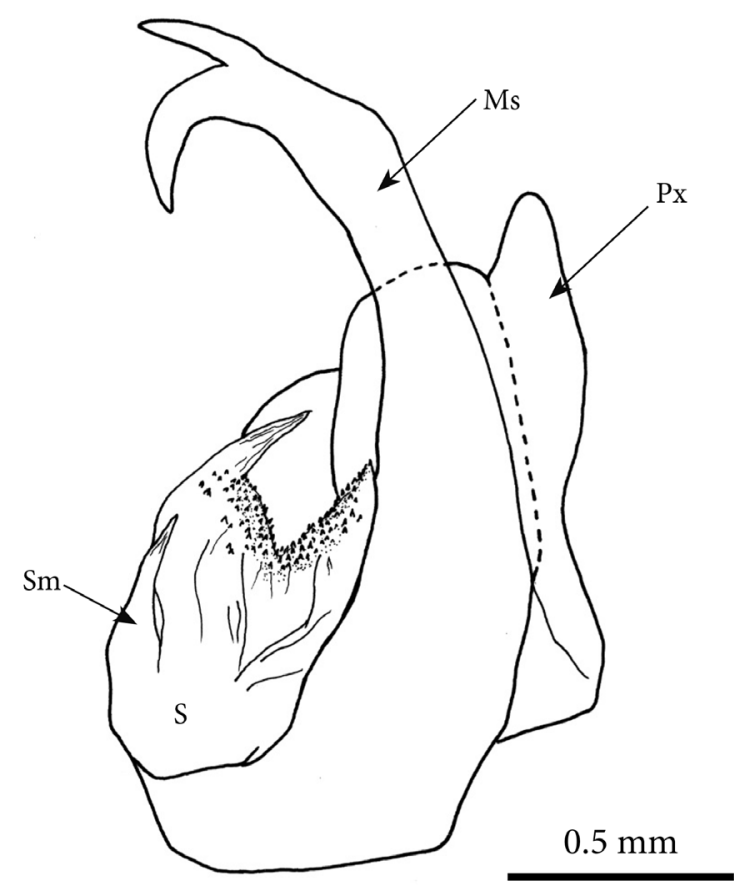

Fig. 8. Ommatoiulus camurus sp. nov. Holotype $\hat{\partial}$, gonopods. A. Right promerite, posterior view. B-D. Right posterior gonopod: B. Mesal view. C. Posterior view. D. Lateral view. 


\section{Ommatoiulus denticulatus sp. nov. urn:Isid:zoobank.org:act:0BBB5341-B3AB-4D79-A593-D86BCB263EAC}

Figs 9-10

Ommatoiulus SP.6 - Bailey \& De Mendonça (1990).

\section{Diagnosis}

Most similar to $O$. alacygni sp. nov. and $O$. staglae sp. nov., but differs by the three-digitate shape of the anterior process of the solenomerite and the strong serrations on the lateral margin of the paracoxite.

\section{Etymology}

The species epithet is a Latin adjective meaning "with small teeth" and refers to the serrations on the lateral margin of the paracoxite.

\section{Material examined}

\section{Holotype}

PORTUGAL: 1 §ै, Beja District, Mértola, in Pine litter, 15. May 1985, P. Bailey leg. (ZMUC).

\section{Paratypes}

PORTUGAL: $1 \hat{\jmath}, 1$, same data as holotype.

\section{Description}

Measurements. Male: $\mathrm{L}=27.7 \mathrm{~mm}, \mathrm{H}=2.5 \mathrm{~mm}, 45 \mathrm{PR}+3 \mathrm{AR}+$ Telson. Female: $\mathrm{L}=27.8 \mathrm{~mm}, \mathrm{H}=$ $2.6 \mathrm{~mm}, 47 \mathrm{PR}+2 \mathrm{AR}+$ Telson.

Colour. Brownish, probably faded after more than 30 years in alcohol. Prozonites pale grey with black sputter, posteriorly forming dorsal triangular spots; metazonites yellowish-brown, with a black sputter posteriorly and scattered setae near the posterior margin (Fig. 9A); dorsum with a thin black mid-dorsal line; legs pale brown to yellowish; head dark brown with dense black sputter, lighter towards the labral zone, mouthparts yellowish; antennae and telson dark, with a dense black sputter. Prozonites with narrow oblique striae; metazonites with regular striation; suture complete, rectilinear but sometimes with a sinus at ozopore level. Anal valves with a marginal row of short setae, a submarginal row of longer ones and ca 5 setae on the disc. Subanal scale triangular, pointed and setose. Preanal ring (Fig. 9B) with 2 setae on the sides, a protruding caudal projection bearing ca 8 setae and a small hyaline straight projection.

Gonopods (FIGS 9C-F, 10). Promerite (P) in posterior view broad at the base, gradually narrowing distad, lateral margin rounded; mesal ridge (Mr) broad and fusing with the mesal margin; rudimentary telopodite (T) not conspicuous. Posterior gonopod: mesomerite (Ms) simple and very reduced; solenomerite (S) complex, broadest at the base, showing an large anterior process ( $\mathrm{Sa}$ ) apically ramified in 3 asymmetrical tips and bearing a subapical median triangular hyaline lamella $(\mathrm{Hl})$; posterior process of the solenomerite (Sp) long with an acuminate tip lodging the opening of the seminal groove 'og'; seminal groove (g) running from the fovea $(\mathrm{F})$ located at the base of the solenomerite up to og; paracoxite (Px) large, twisted meso-posteriad, distally leaf-shaped with a pointed apex and showing strong serrations on the lateral margin; coxa $(\mathrm{Cx})$ large and rounded.

\section{Distribution}

Southeast Portugal, Mértola. 

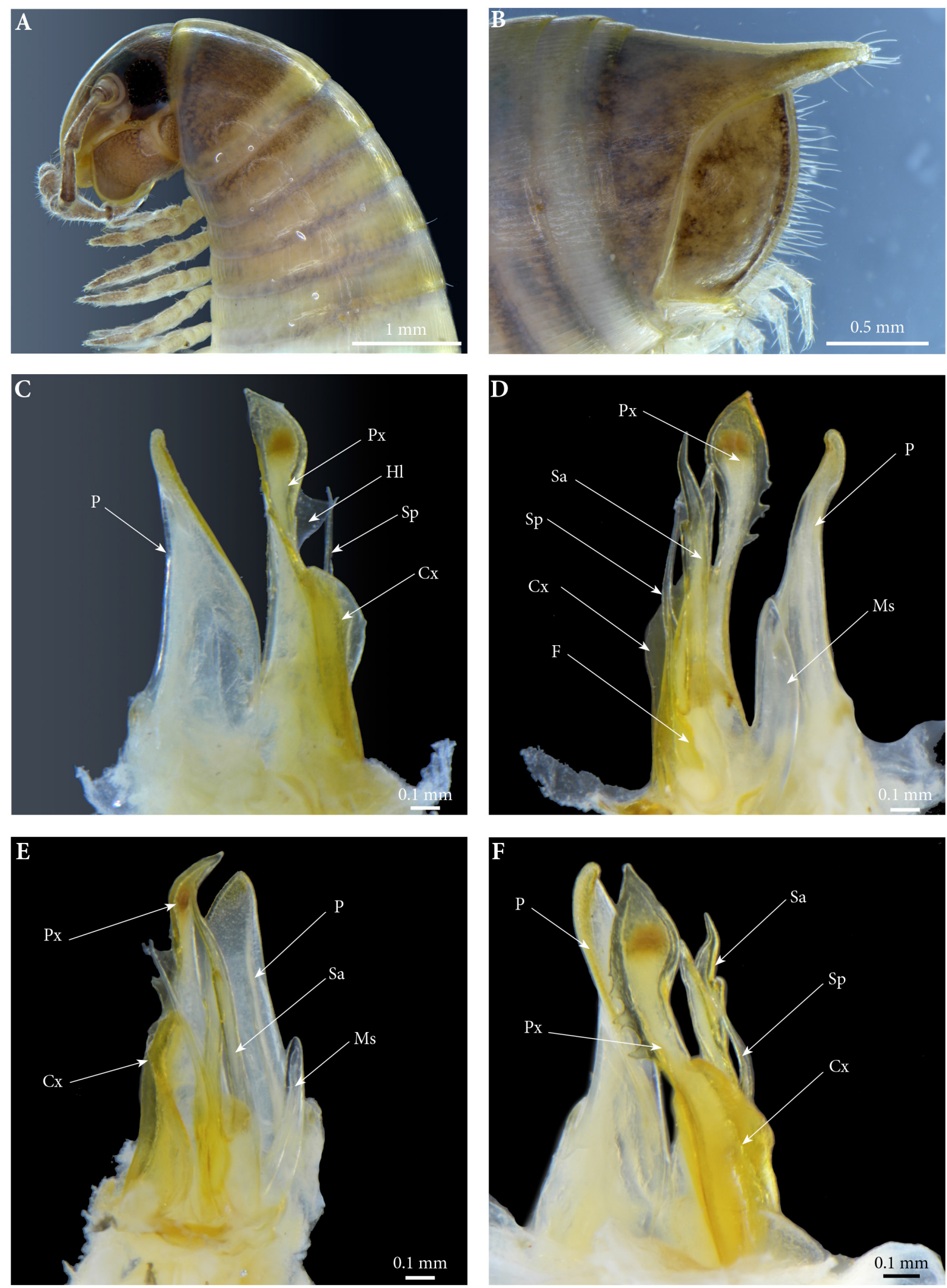

Fig. 9. Ommatoiulus denticulatus sp. nov. Holotype $\delta$. A. Head and anteriormost body-rings, lateral view. B. Telson, lateral view. C. Right gonopod, lateral view. D. Right gonopod, mesal view. E. Right gonopod, posterior view. F. Right gonopod, postero-lateral view. 
A

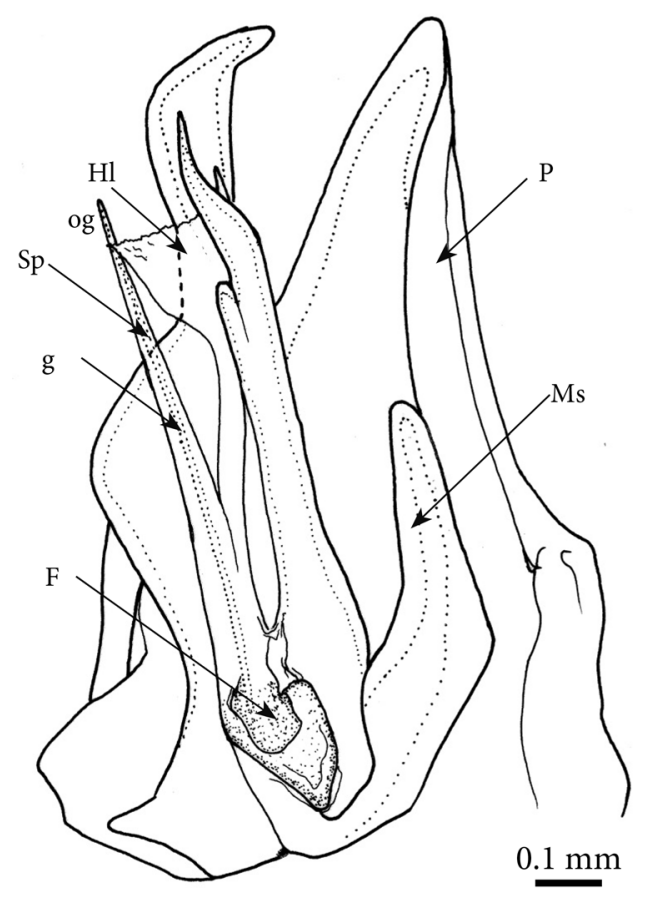

B

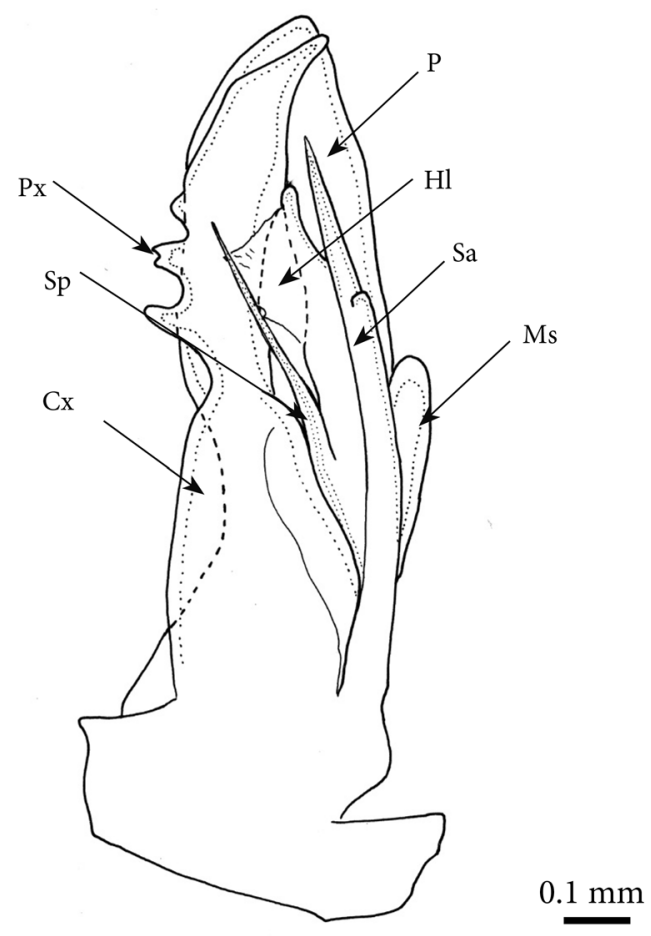

Fig. 10. Ommatoiulus denticulatus sp. nov. Holotype $\widehat{\jmath}$. A. Right gonopod, mesal view B. Right gonopod, posterior view.

Ommatoiulus dorsovittatus (Verhoeff, 1893)

Julus (Hemipodoiulus) dorsovittatus Verhoeff, 1893b: 157-158, figs 24, 27.

Schizophyllum dorsovittatum estrellanum Verhoeff, 1910: 203-204, figs VII, 22, 22b, XXI.

Schizophyllum calatravanum Brolemann, 1920: 136-138, figs 11-13. Synonymized by Akkari \& Enghoff 2012: 16.

Palaioiulus dorsovittatus - Verhoeff 1894: 157, Taf. VI, fig. 22.

Ommatoiulus calatravanum - Mauriès 1978: 585.

Ommatoiulus dorsovittatus - Vicente 1985: 323.

Ommatoiulus dorsovittatus estrellanus - Vicente 1985: 323.

Ommatoiulus dorsovittatus - Akkari \& Enghoff 2012: 16-19, figs 34-40.

\section{Descriptive notes}

See Akkari \& Enghoff (2012).

\section{Distribution}

PORTUGAL: Coimbra Province (Verhoeff 1893b, as Julus dorsovittatus), Serra da Estrela (Verhoeff 1910, as S. d. estrellanum).

SPAIN: Pozuelo de la Calatrava (Brolemann 1920) and Andalusia (Akkari \& Enghoff 2012).

\section{Comments}

The record from Portugal is only based on literature resources. 
Ommatoiulus fuentei (Brolemann, 1920)

Fig. 11

Schizophyllum (Eleutheroiulus) Fuentei Brolemann, 1920: 132-136, figs 7-10

Ommatoiulus fuentei - Mauriès 1978: 585. — Vicente 1985: 323. — Akkari \& Enghoff 2012: 19-21

\section{Material examined}

PORTUGAL: $7 \lesssim \widehat{\jmath}, 4$ 우, Evora District, ca $10 \mathrm{~km}$ W of Mourão on Evora road, beneath Pine trees, eating moss on rocks, 18 Oct. 1986, species n. 26, site 25, P.T. Bailey leg. (ZMUC).

\section{Descriptive notes}

See Akkari \& Enghoff (2012).

\section{Distribution}

South Spain (Ciudad Real, Andalusia, Estremadura) and south Portugal.

\section{Comments}

This is the first record of $O$. fuentei from Portugal. The species was initially described from Ciudad Real and was subsequently recorded from Estremadura and Andalusia (Akkari \& Enghoff 2012).

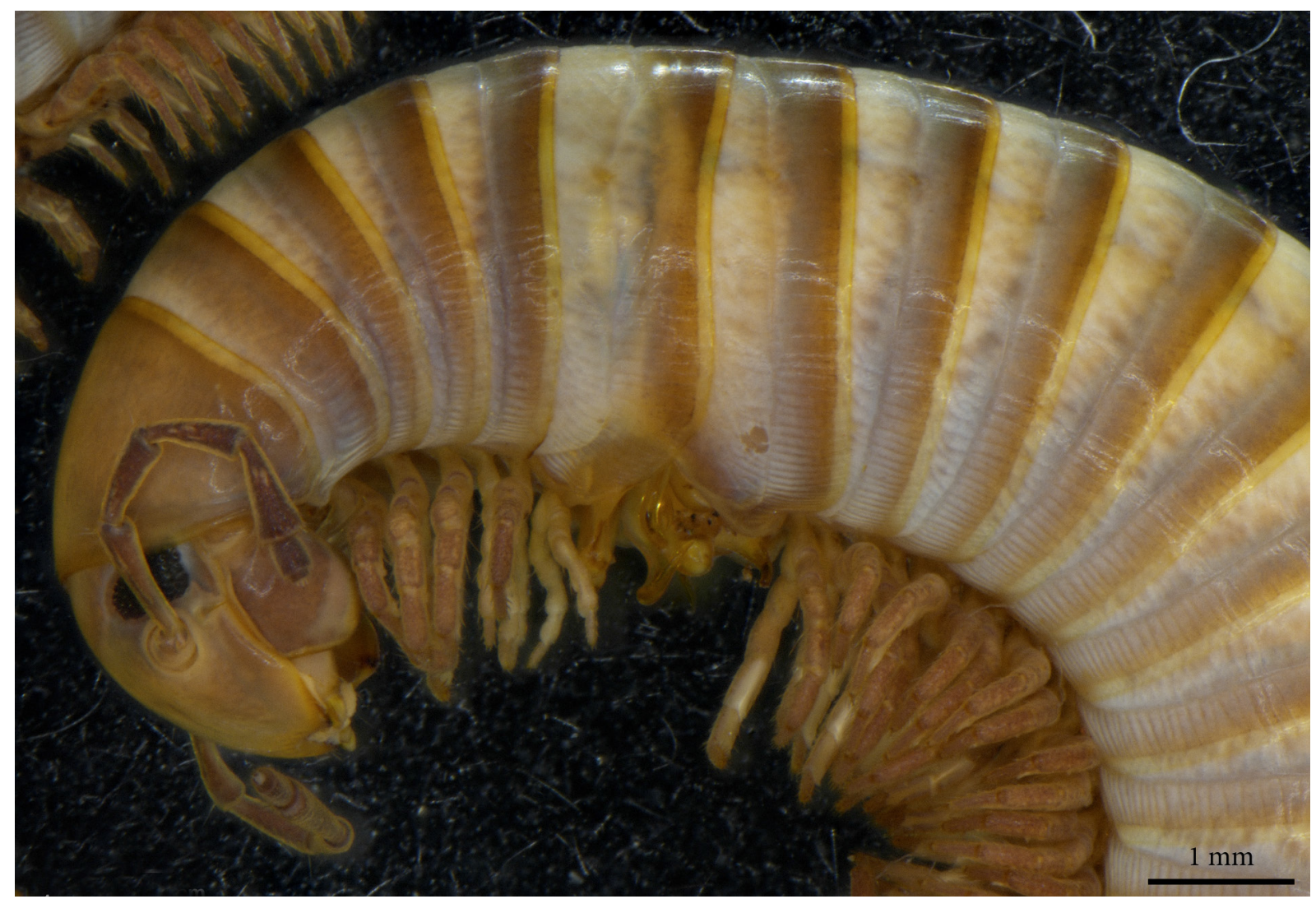

Fig. 11. Ommatoiulus fuentei (Brolemann, 1920), ô from Mourão, head and anteriormost body rings, lateral view. 


\section{Ommatoiulus litoralis sp. nov \\ urn:1sid:zoobank.org:act:4BCEFAB9-9C52-4C42-958F-A7EB03707221}

Figs $12-14$

Ommatoiulus SP.4 - Bailey \& De Mendonça (1990)

\section{Diagnosis}

Similar to O. moreleti (Lucas, 1860) and O. bipartitus with a solenomerite divided into 3 processes and bearing a distolateral lamella and a broad distally expanding paracoxite but different in everything else.

\section{Etymology}

The species epithet is a Latin adjective meaning "of the coast" and refers to the affinity of the specie with coastal habitats.

\section{Material examined}

\section{Holotype}

PORTUGAL: 1 O̊, Faro District, Cape St. Vincent, near Sagres, under low bush, in litter, 10 Apr. 1987, P.T. Bailey leg. (ZMUC), Bailey sp. 4.

\section{Paratypes}

PORTUGAL: 1 q, 2 juveniles, same data as the holotype; 1 ô, Faro District, Aljezur Province, Praia de Bordeira, sandy dunes, 37.193917 N, 8.904633 W, alt. 50 m, 12 Apr. 2005, P. Cardoso leg. (ZMUC); 1 J , Faro District, Algarve, Cape St. Vincent, 2 Mar. 1981, D. Kime leg. (NHMW 8741).

\section{Description}

Measurements. Males: $\mathrm{L}=25.3-27.8 \mathrm{~mm}, \mathrm{H}=1.7-2.4 \mathrm{~mm}, 40-43 \mathrm{PR}+2 \mathrm{AR}+$ Telson. Female: $\mathrm{L}=$ $37.4 \mathrm{~mm}, \mathrm{H}=2.9 \mathrm{~mm}, 42 \mathrm{PR}+2 \mathrm{AR}+$ Telson.

Colour. Light brown, mostly faded in alcohol (Fig. 12). Prozonites dark brownish, with black sputter denser on the lateral side at the line of ozopores (Fig. 12B) and forming triangular spots along the middorsal line, metazonites pale whitish and translucent; dorsum with a thin black mid-dorsal line; legs pale brown to yellowish; head light brownish (Fig. 12A), mouthparts bright yellowish; anal valves with obviously faded black sputter, preanal ring pale (Fig. 12C). Prozonites with oblique striae; metazonites with regular striation; suture complete, rectilinear but sometimes with a sinus at ozopore level. Anal valves setose with a marginal row of short setae, a submarginal row of longer ones and 1-2 (? perhaps more, broken) setae on the disc. Subanal scale triangular, pointed and setose. Preanal ring with a protruding caudal projection with $(5+5)$ setae and bearing a straight, relatively thick hyaline process.
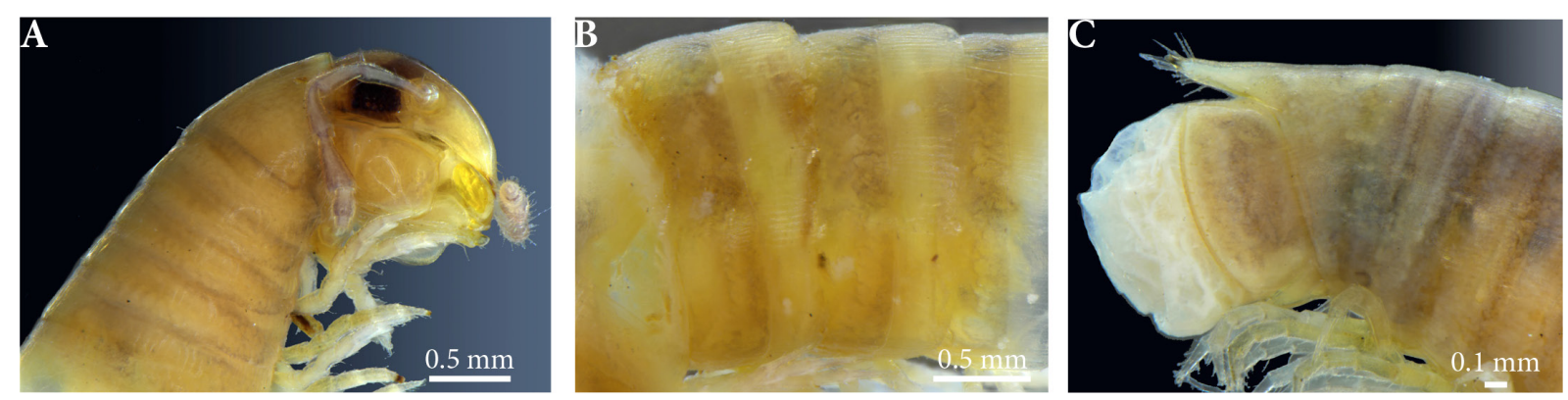

Fig. 12. Ommatoiulus litoralis sp. nov. Paratype, $\widehat{\partial}$ from Aljezur, lateral views. A. Head and anteriormost body rings. B. Mid-body rings. C. Posterior-most body rings. 
Gonopods (Figs 13, 14). Promerite $(\mathrm{P})$ in posterior view slender, subrectangular with parallel margins and slightly curved laterad; mesal ridge (Mr) thin, merging with the mesal margin and distally ending in serrated subapical process; apically almost straight, showing a small hyaline process extending beyond the apical margin; rudimentary telopodite $(\mathrm{T})$ oval, consipicuous on the posterior surface at mid-length of the promerite. Posterior gonopod (Figs 13, 14): Mesomerite (Ms) slender and curved anteriad to nest against the promerite, apically narrowing into a pointed tip; solenomerite (S) large with 3 distinct processes: an anterior process $(\mathrm{Sa})$ the longest, gently narrowing apically and curved anteriad, a median process distally bearing a hyaline lamella $(\mathrm{Hl})$ and a posterior process $(\mathrm{Sp})$ the thinnest and most acuminate apically lodging the opening of the seminal groove 'og'; the seminal groove (g) running from
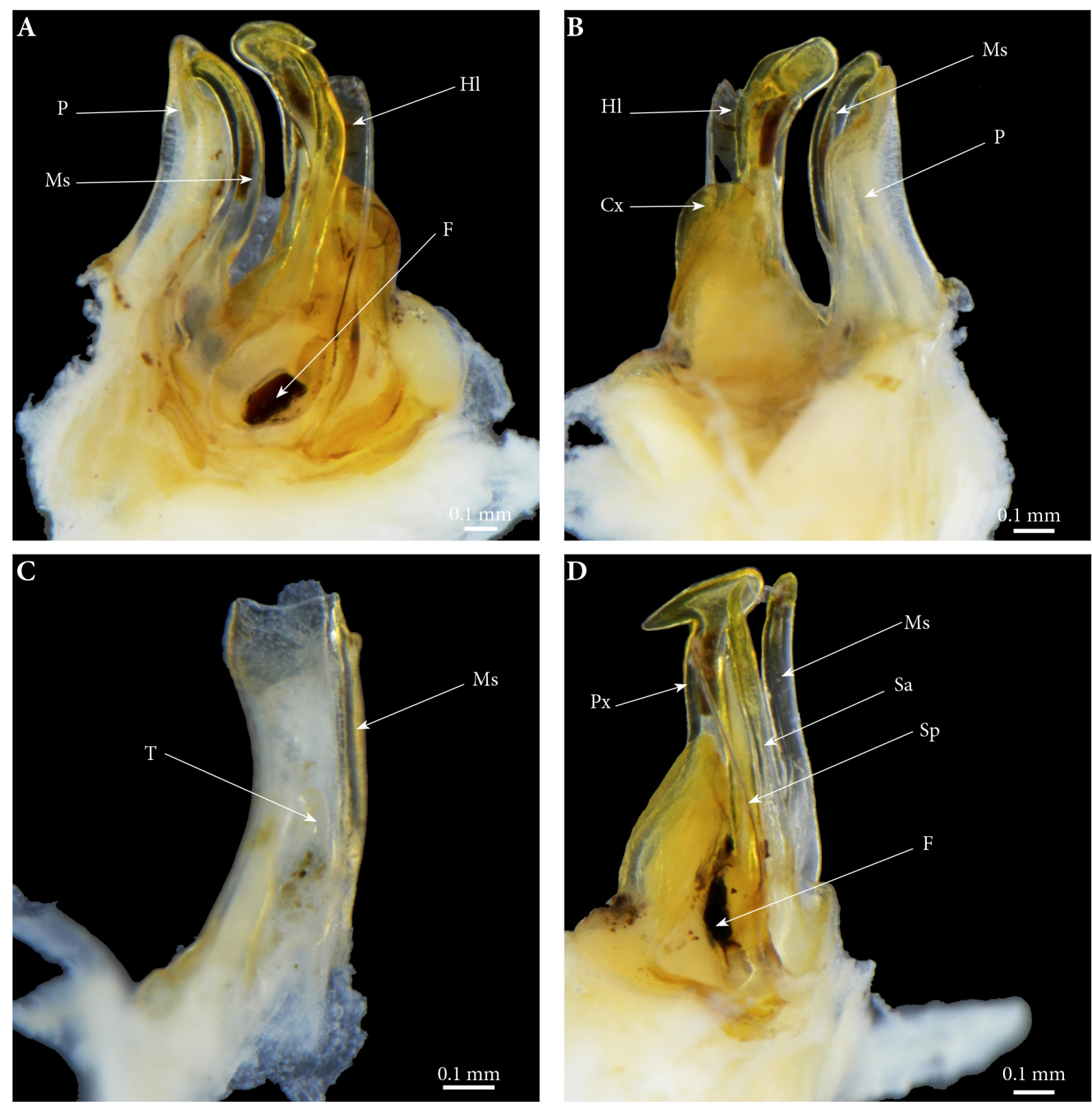

Fig. 13. Ommatoiulus litoralis sp. nov. Paratype, ô from Algarve, gonopods. A. Left gonopod, mesal view. B. Left gonopod, lateral view. C. Right promerite, posterior view. D. Right posterior gonopod, postero-mesal view. 
the fovea (F) located at the base of the solenomerite up to og; paracoxite (Px) broad, distally expanding in a hammer-shaped process pointing posteriad; coxa $(\mathrm{Cx})$ large and rounded, protruding distad.

\section{Distribution}

South Portugal, Algarve.
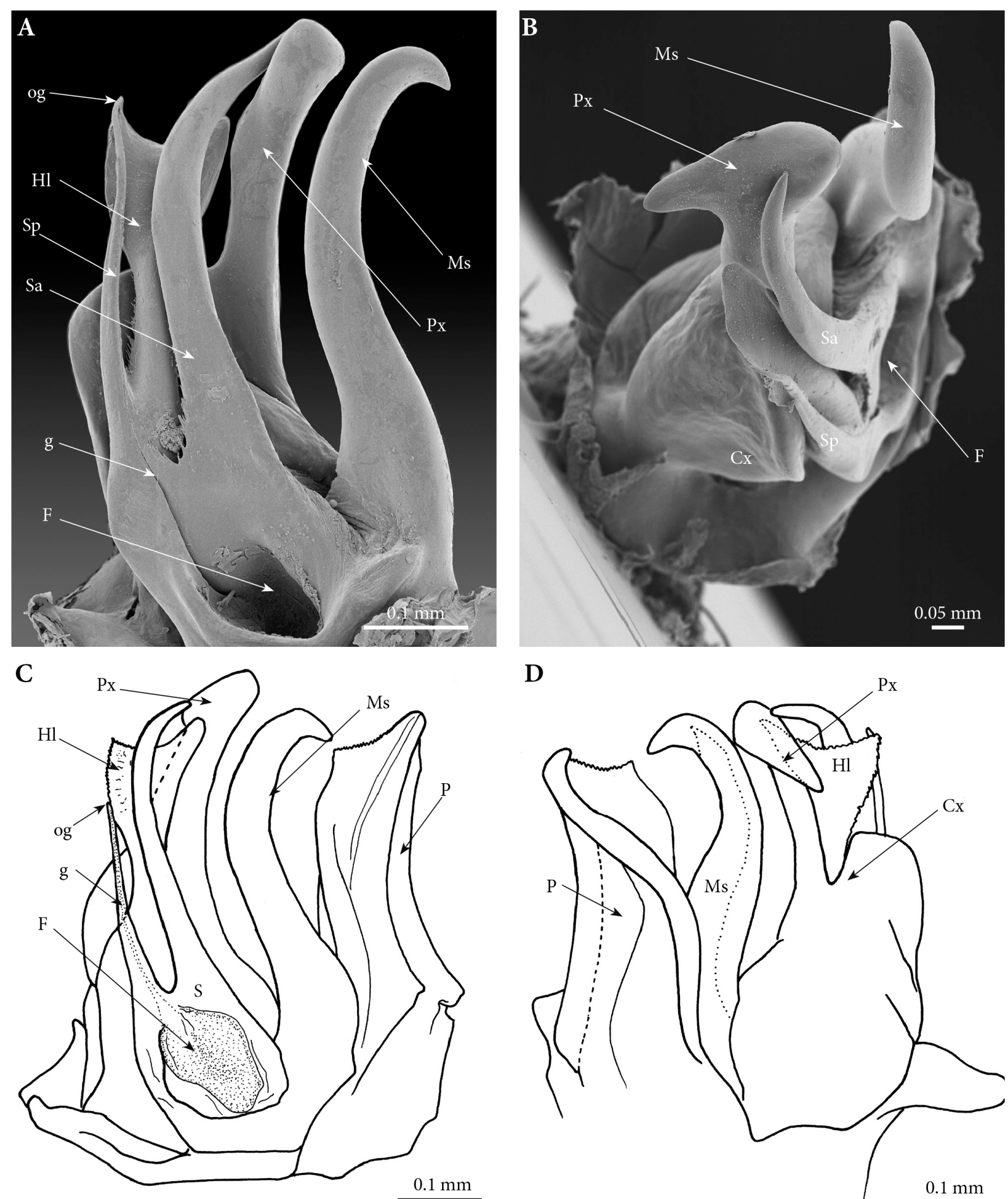

D

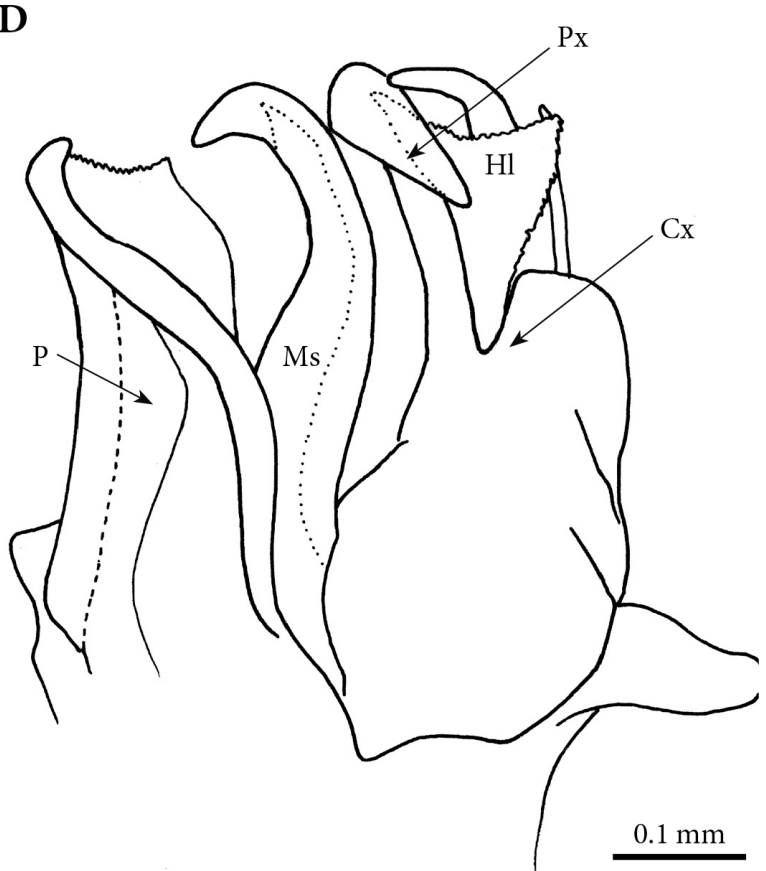

Fig. 14. Ommatoiulus litoralis sp. nov. A-B. Paratype, ô from Aljezur, right gonopod. A. mesal view. B. Disto-mesal view. C-D. Paratype, ô from Algarve, right gonopods. C. mesal view. D. lateral view. 
Ommatoiulus lusitanus (Verhoeff, 1895)

Fig. 15

Schizophyllum (Eleutheroiulus) lusitanum Verhoeff, 1895: 224-226.

Archiulus (Schistocoxitus) cingulatus Attems, 1927: 286-288, figs 79-85 new syn.

Ommatoiulus cingulatus - Vicente 1985: 323. — Bailey \& De Mendonça 1990: 104.

\section{Diagnosis}

Large species, closest to O. sabinarensis Akkari, Mauriès and Enghoff, 2012, both are the only Iberian species with a deeply divided paracoxite. The two species also share similarities in the configuration of the solenomerite characterized by a strongly serrated main process and two accessory branches of different shapes. The two species differ in the main shape of the promerite, mesomerite and a much lower solenomerite and simpler accessory branches in $O$. lusitanus.

\section{Material examined}

PORTUGAL: Schizophyllum (Eleutheroiulus) lusitanum, syntype slide preparation(ZMB 130856) which is herewith designated as a lectotype; gonopods in slide preparation (NHMW3162) designated herewith as a lectotype for Archiulus (Schistocoxitus) cingulatus, $7 \hat{\jmath} \hat{\jmath}, 2$ 웅 (NHMW8810) paralectotypes

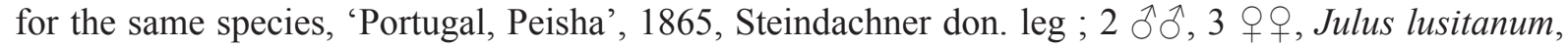
syntypes, don. Verhoeff 1896, Coimbra Env., Paulino d'Oliveira leg. (NHMW8045); 1 ภ, approx. 12 km SW Évora Province, 38,475889 N, 8,027 W, 27 Mar. 2012, I. Martínez-Solano, J. Gutiérrez, E. Recuero leg. (Ernesto Recuero Coll. 1790); 1 đ, 1 \%, Setúbal District, Grândola, under stones in grassland, 3

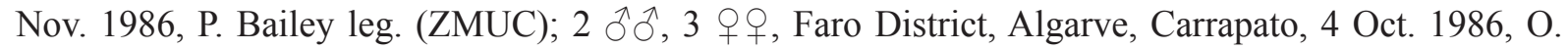
Martin leg. (ZMUC); 1 ô, 4 우, 4 juveniles, Faro District, Baragem de Bravura, 5 Mar. 1981, D. Kime

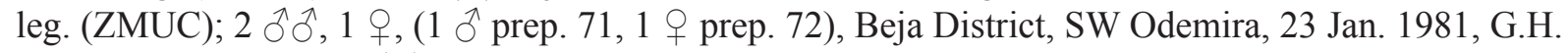

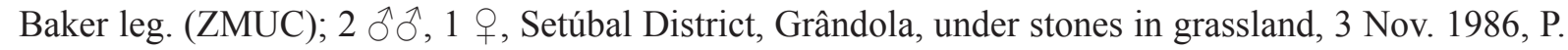
Bailey leg. (ZMUC); 1 §ึ, 3 우, 70 km SE of Lisboa, 27 Oct. 1981, G.H. Baker leg. (ZMUC).

\section{Descriptive notes}

Promerite with a round apex and a deep lateral notch (Fig. 15A-B). Posterior gonopods complex (Fig. 15C-D) with a large, club-shaped mesomerite (Fig. 15E-F), distally expanded mesolaterad, apically with a thin process pointing distad. Solenomerite complex with a main short bulgy process, deeply furrowed, posterior half strongly serrated and apically protruding in an acuminate stem lodging the opening of the seminal groove, anteriorly with a long slender process; paracoxite large and deeply divided in two asymmetrical branches.

\section{Distribution}

Portugal.

\section{Habitat}

Predominantly in grassland but occurring in Cistus litter (Bailey \& De Mendonça 1990).

\section{Comments}

Verhoeff (1895) described Schizophyllum (Eleutheroiulus) lusitanum from Coimbra without providing any illustration of the gonopods, but his verbal description, although in part difficult to interpret, is consistent with the much better described Archiulus cingulatus Attems, 1927. For example, in Verhoeff's description of the mesomerites ("Mittelblätter") he wrote (translated from German): "the latter ends apically in a pointed tooth. A second such [tooth] projects at approximately right angles on the lateral 

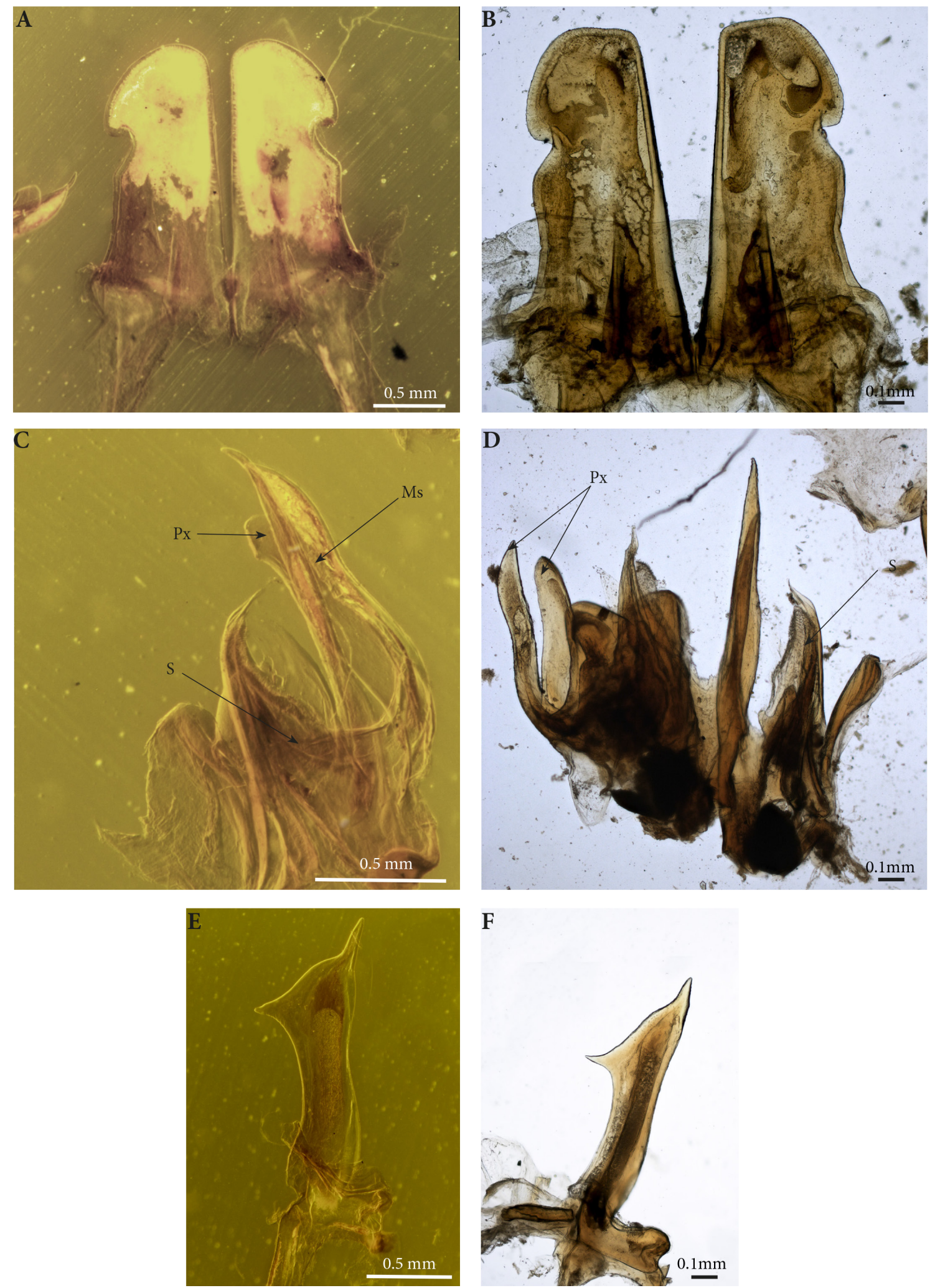

Fig. 15. Ommatoiulus lusitanus (Verhoeff, 1895). A, C, E. 'Archiulus cingulatus' syntype (NHMW 3162). B, D, F. Schizophyllum (Eleutheroiulus) lusitanum, syntypes, slide preparation (ZMB 130856). A-B. Promerites, posterior view. C-D. Posterior gonopods, posterior view. E-F. Mesomerites, posterior view. 
side somewhat distal to the mid-length", cf. Fig. 15E, F. Verhoeff donated a few syntypes of the species to NHMW; these were probably overlooked by Attems who in 1927 described Archiulus cingulatus based on material from 'Peisha' (probably Baja now), and for which he even erected the subgenus Schistocoxitus based on the unique shape of the paracoxite deeply divided in two processes (now also noted for the Andalusian species Ommatoilus sabinarensis Akkari, Mauriès \& Enghoff, 2012).

The comparison side by side of the syntypes of $O$. lusitanum and $O$. cingulatus (see Fig. 15) from ZMB and NHMW collections respectively leaves no doubt that both names are synonyms. Therefore, Archiulus cingulatus is here considered as a junior synonym of Ommatoiulus lusitanus (Verhoeff, 1895).

Ommatoiulus martensi Mauriès, 1969

Ommatoiulus martensi Mauriès, 1969: 332-334, figs 6-10. — Mauriès 1971: 114.

\section{Material examined}

PORTUGAL: 2 ふึึ, 2 우, Coimbra, Serra da Estrela, 1900 m, 9 Jul. 1979. G. Osella leg. (MCSNV).

\section{Comments}

The examined specimens agree perfectly with the original description, type material and with neartopotypes examined by HE [Spain, Cantabria, Parque Nacional de los Picos de Europa, Fuente de El Cable, 22 Sep. 2014, V. Ortuño leg., (ZMUC)], and are the only ones of this species recorded from Portugal.

Ommatoiulus martensi was described from Santander in Spain, together with another species, Ommatoiulus haackeri Mauriès, 1969 from Col du Pourtalet in France at ca $435 \mathrm{~km}$ distance (Mauriès 1969). Both species have subsequently been identified from several localities in Western Pyrenees in Spain (O. martensi) and from northern Spain and the Basque country (O. haackeri). These two species have nearly the same gonopod configuration with main differences lying in 1) shape of the apical process of the promerite; 2) length of the distal process of solenomerite and 3) shape of the lateral process of the paracoxite (Mauriès 1969). After examination of several specimens we have failed to assign some of them to either haackeri or martensi with certainty. However, we assign the Portuguese species to O. martensi though a revision of the taxonomy of both (nominal) species is planned for a revision of the genus Ommatoiulus of northern Spain.

\section{Ommatoiulus moreleti (Lucas, 1860)}

Fig. 16

Schizophyllum cervinum Verhoeff, 1910: 200-202, figs XI, XII, XXIV new. syn.

For a complete list of synonyms see Akkari \& Enghoff 2012: 31.

\section{Material examined}

PORTUGAL: Schizophyllum (Hemipodoiulus) cervinum, syntypes (ZMB4837, ZMB13652), Verhoeff's micro-preparation (ZMB3896), Serra da Estrela, Bolivar leg.; 1 q Schizophyllum (Hemipodoiulus) cervinum, syntype, Serra da Estrela, don. Verhoeff 1908 (NHMW3155); Julus karschi Verhoeff, 1892 syntypes, 1 ㄱ, 3 q우, Portugal, Coimbra environs, A.F. Moller leg. (NHMW 8050); Julus karschi Verhoeff, 1892 syntypes; 1 ô, 4 우, 1 juvenile, 1 intercalary male, Portugal, Coimbra, Moller leg. (NHMW 8051); 1 § , Leiria, Gruta de Santo António de Alvados, 39.532131 N, 8.7334558 W, 9 Mar. 2012, M.G. París leg. (E. Recuero Coll. 1730); 2 $\widehat{\jmath}$, Faro District, Algarve, Albufeira, 23 Sep. 1996, O. Martin leg. (ZMUC); 1 ô, 1 + , 1 juvenile, Faro District, Algarve, Monchique, 23 Sep. 1996, O. 
Martin leg. (ZMUC); 1 ð̊, Faro District, Algarve, Alferce, 37.342833 N, 8.483972 W, 3 Jan. 2013, M.G.

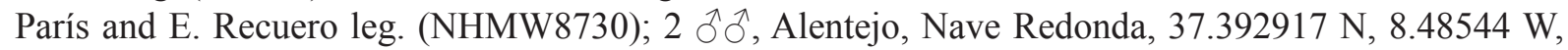
4 Jan. 2013, M.G. París and E. Recuero leg. (NHMW 8731; NHWM 8732); 1 ðै, Alentejo, Luzianes, 37.616639 N, 8.4655 W, 4 Jan. 2013, M.G. París and E. Recuero leg. (NHMW 8733); 1 §, Algarve,

A

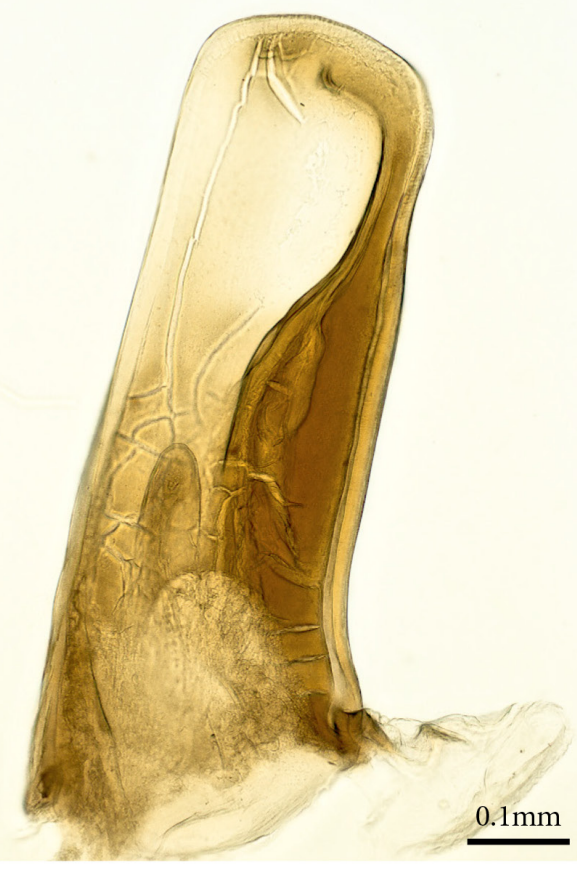

C

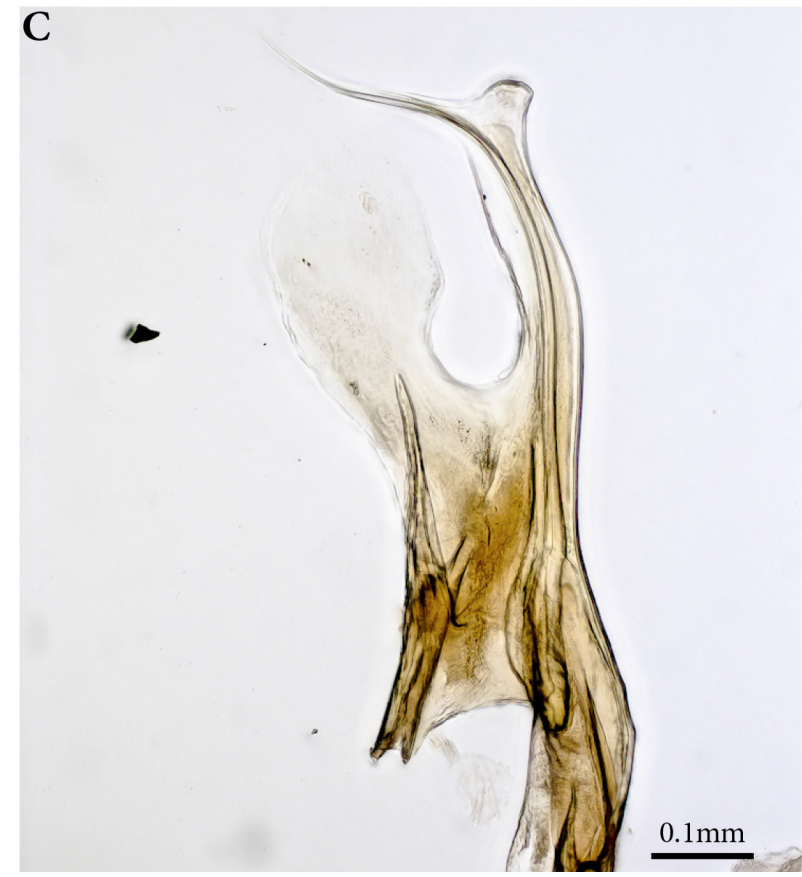

B

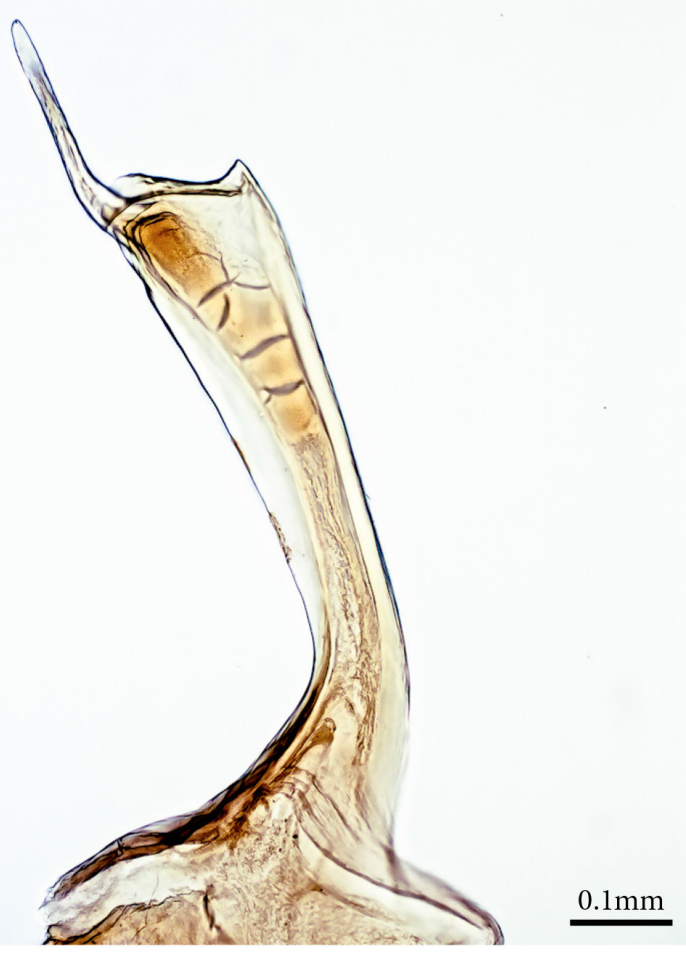

D

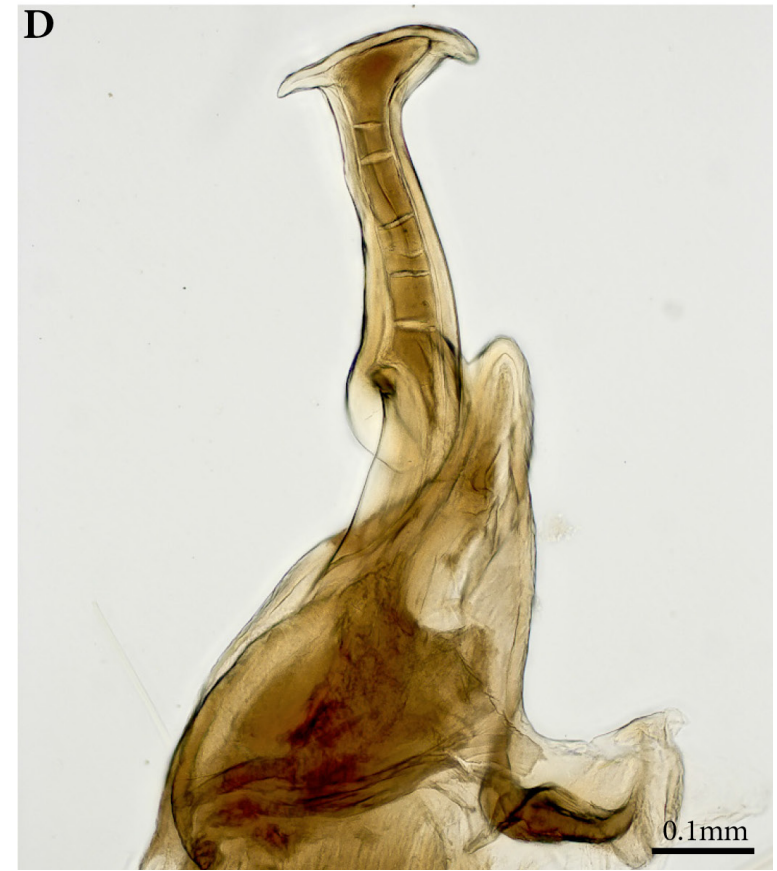

Fig. 16. 'Schizophyllum cervinum'Verhoeff, 1910, syntype, gonopod, slide preparation (ZMB 3896). A. Promerite, posterior view. B. Mesomerite, posterior view. C. Solenomerite, anterior view. D. Paracoxite, anterior view. 
Monchique, Alcaria do Peso, 37.3393306 N, 8.559222 W, 4 Jan. 2013, M.G. París and E. Recuero leg. (NHMW 8734); 1 ð̄, Pataias, 39.679167 N, 9.002222 W, 2 Jan. 2012, I. Martinez-Solao and P. Pavón leg. (NHMW 8735).

\section{Distribution}

O. moreleti is widespread in Portugal and western Spain (see maps in Baker 1984). It has been introduced to the Macaronesian Islands, Bermuda, South Africa and notably Australia, where it is known as a pest under the name of the "Portuguese millipede".

\section{Comments}

This species, which has become widespread through commerce, and which exhibits considerable gonopodal variation (e.g., Baker 1984), has been the source of much taxonomic confusion. Verhoeff (1910) described Schizophyllum cervinum from Serra da Estrela in Portugal and provided illustrations of isolated gonopod processes: promerite, paracoxite and mesomerite (see Abb. XI, XII, XXIV). In his description for the species, Verhoeff (1910) underlined the important similarities between this species and Ommatoiulus moreleti. The examination of Verhoeff's slide preparations of a cervinum ZMB3692, which we herewith designate as a lectotype for Schizophyllum cervinum (see Fig. 16) leaves no doubt that Schizophyllum cervinum is actually a junior synonym of Ommatoiulus moreleti (Lucas, 1860) with which it agrees in the shape of all gonopod processes.

\section{Ommatoiulus oliveirae (Verhoeff, 1893)}

Fig. 17

Julus oliveirae Verhoeff, 1893b: 161-163, figs 27-28.

Palaioiulus oliveirae - Verhoeff 1894: 156, fig. III

Ommatoiulus oliveirae - Vicente 1985: 324. — Bailey \& De Mendonça 1990: 104.

\section{Material examined}

PORTUGAL: Syntype, gonopods, slide preparation (ZMB13086) herewith designated as lectotype of Julus oliveirae; 3 ડิ $\widehat{\jmath}, 3$ 우, 1 slide preparation, undetermined locality, Paulino d'Oliveira leg. (NHMW 8044); 2 ડ̄ $\widehat{0}, 1$ ㅇ, Setúbal District, Grândola, under stones, in grassland, 3 Nov. 1986, P. Bailey leg. (ZMUC).

\section{Diagnosis}

Most similar to $O$. armatus and $O$. dorsovittatus in the voluminous solenomerite with lobes and a serrated furrow, the presence of a lateral notch on the promerite and the reduced paracoxite. Different in the distal part of the mesomerite, promerite and a more slender shape of the solenomerite and paracoxite.

\section{Descriptive notes}

Promerite simple, in posterior view gradually narrowing in its distal half, apex rounded and lateral margin shallowly incised (Fig. 17A, C); mesomerite (Ms) large, extending beyond the rest of the processes, curved laterad and distally expanding into two oppositely directed processes (Fig. 17B, D); solenomerite (S) with a main process reaching $2 / 3^{\text {rd }}$ of mesomerite length, marginally strongly serrated, apically with a rounded lobe covered with short spines and a small pointed accessory process (Fig. 17D), paracoxite (Px) slender, almost as long as solenomerite (Fig. 17B, D) and emerging from a broad coxa (Cx).

\section{Distribution}

PORTUGAL: Coimbra (Verhoeff 1893b); Setubal Province, Grândola where it is sympatric with O. moreleti and O. lusitanus (Bailey \& De Mendonça 1990). 
Additional records (Kime, pers. comm.): Faro Province, West of Monchique, in cork litter, 29 Sep. 1987, P.T Bailey.

\section{Habitat}

Abundant in Quercus litter but also found in Cistus litter, also occurring in grasslands (Bailey \& De Mendonça 1990), syntopic with O. moreleti and O. lusitanus.
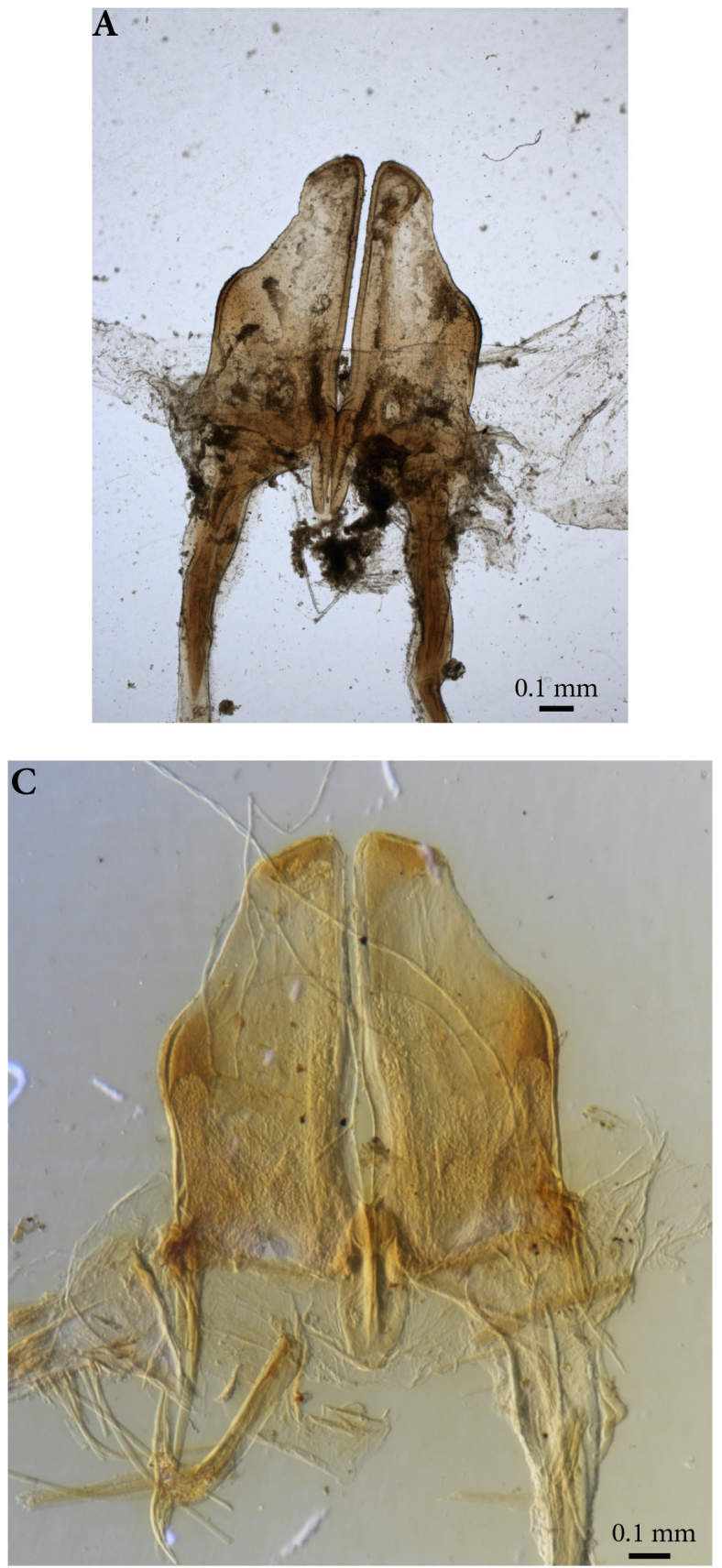
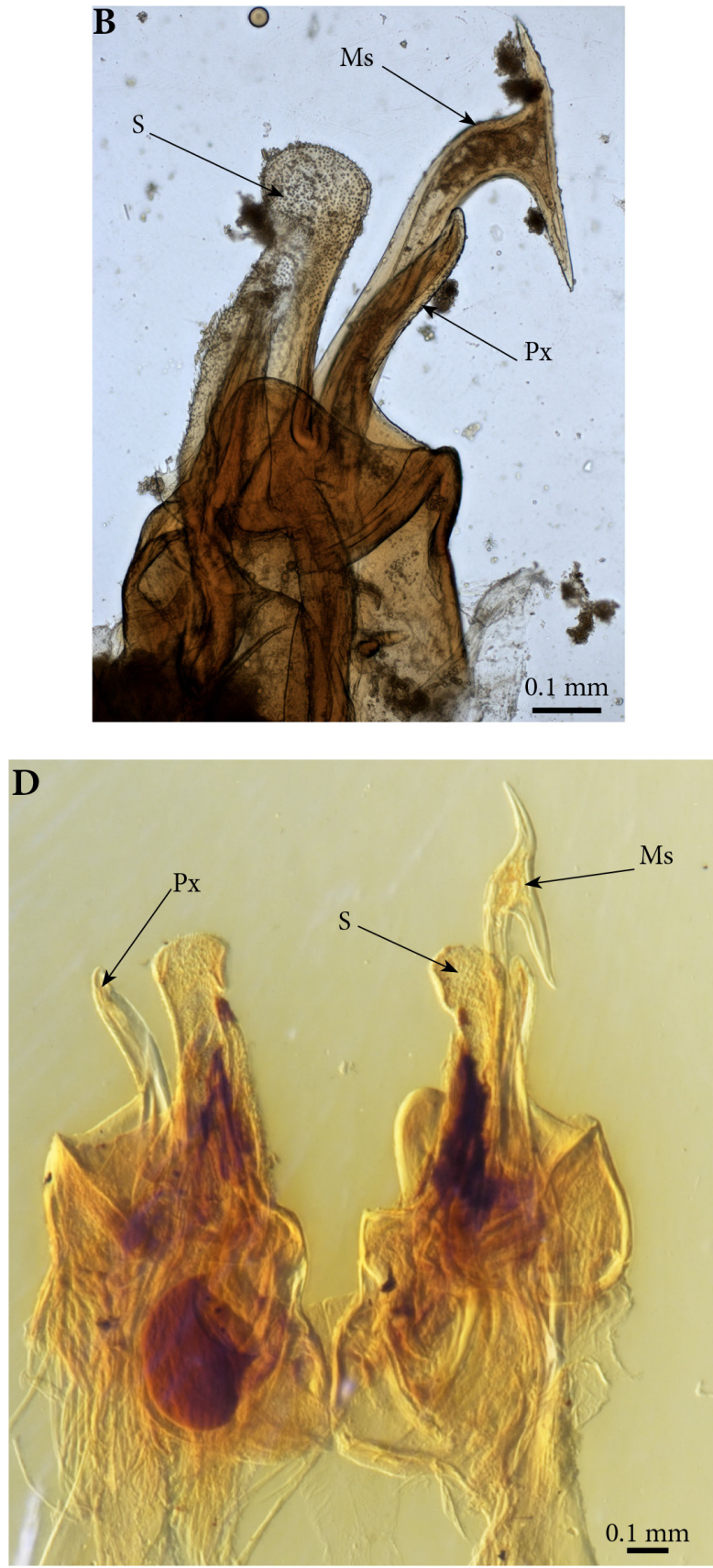

Fig. 17. Ommatoiulus oliveirae (Verhoeff, 1893). A-B. Syntype, slide preparation (ZMB 13086). A. Promerites, posterior view. B. Posterior gonopod, posterior view. C-D. Slide preparation (NHMW 8044). C. Promerites, posterior view. D. Posterior gonopods, posterior view. 
Ommatoiulus porathi (Verhoeff, 1893)

Fig. 18

Julus porathi Verhoeff, 1893b: 166-167.

Palaioiulus porati [sic!] - Verhoeff 1894: 159, figs 10-11.

Schizophyllum porati [sic!] - Verhoeff 1921: 53.

\section{Diagnosis}

Small species, most similar to $O$. sabulosus (Linnaeus, 1758) both having a promerite with no incision and gently narrowing distally, a simple and slender mesomerite, a solenomerite bearing a long mesal projection lodging the opening of the seminal groove and a distal lamella, and a simple and stout paracoxite. Different in the shape of the distal lamella of the solenomerite and also in the shape of the mesomerite and paracoxite.
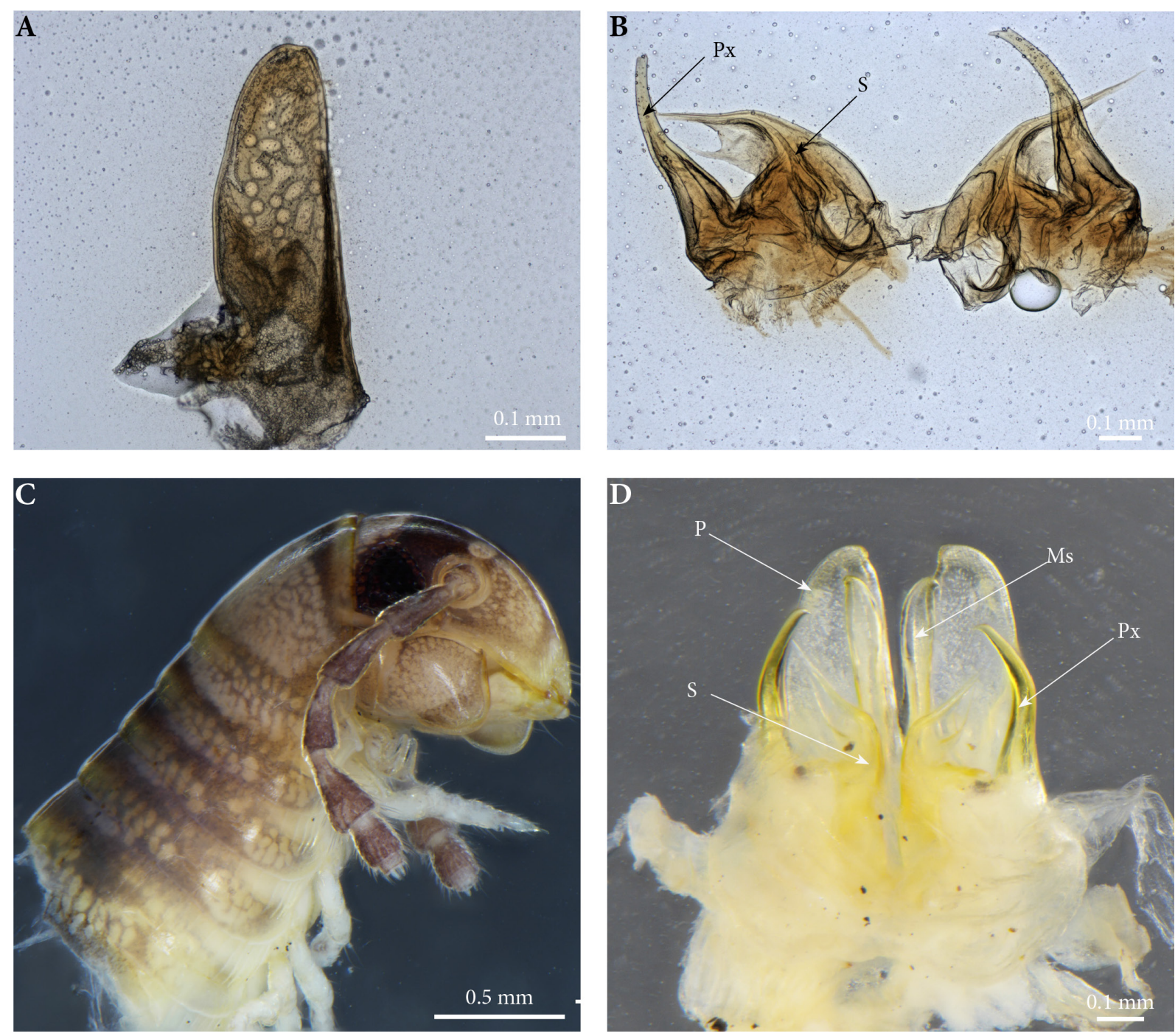

Fig. 18. Ommatoiulus porathi (Verhoeff, 1893). A-B. Holotype $\widehat{\alpha}$, Verhoeff's slide preparation 1190, (ZMB). A. Right promerite, posterior view. B. Posterior gonopods. C-D. § from Viseu, (NHMW 8736). C. Head and anterior rings, lateral view. D. Gonopods, posterior view. 


\section{Material examined}

\section{Holotype}

PORTUGAL: Julus porathi Verhoeff, 1893, micro-slide (ZMB); 1 §̊, Viseu Province, Serra do Caramulo, 40.593006 N, 8.163114 W, 6 Mar. 2012, N. Percino, M.G. París leg. (NHMW 8736).

\section{Distribution}

Central Portugal: Coimbra (Verheoff 1921), Viseu.

\section{Comments}

Ommatoiulus porathi was described verbally by Verhoeff (1893b), based on two males and six females. One year later, Verhoeff (1894) provided drawings of the mesomerite and opisthomerite, and in 1921 he included O. porathi in the identification key for the subgenus Bothroiulus (Verhoeff, 1921). The species has, however, never been collected again until now and has been regarded as dubious. The newly collected specimen agrees entirely with Verhoeff's description, and its gonopods agree perfectly with those of the type specimen (Fig. 18). O. porathi is, together with O. stellaris sp. nov. (see description below), one of the smallest known Ommatoiulus species. Verhoeff (1893b) didn't give any measurements but merely stated that it is a little bit smaller than Leptoiulus trilineatus (C.L. Koch, 1847).

\section{Ommatoiulus staglae sp. nov. urn:Isid:zoobank.org:act:843168C3-8C9A-49B1-AE9F-528789B63930}

Figs 19-21

Ommatoiulus SP.7 - Bailey \& De Mendonça (1990)

\section{Diagnosis}

Most similar to $O$. alacygni sp. nov. and $O$. denticulatus sp. nov. sharing the above mentioned characters for the group (see diagnosis of $O$. alacygni); different by the bipartite solenomerite with a long sinuous branch bearing a pointed accessory branch and a shorter one ending in a curved 'fish-tail' process and the absence of conspicuous serrations on the coxa and paracoxite.

\section{Etymology}

The species is named in honour of Verena Stagl, for her considerable effort (1995-2014) in organizing and curating the legacy collection of Carl Attems and Robert Latzel in the Natural History Museum Vienna, one of the most impressive historical collections of Myriapoda in Europe.

\section{Material examined}

\section{Holotype}

PORTUGAL: 1 ô, Faro District, Chilrão, 12 km W of Monchique in litter of green shrub, 29 Sep. 1987 P.T. Bailey leg. (NHMW 8737).

\section{Paratypes}

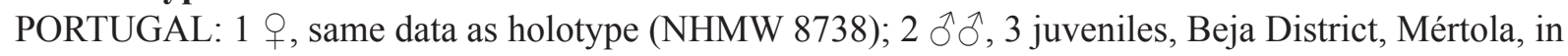
Pine litter, 15 Oct. 1987, P.T. Bailey leg. (ZMUC).

\section{Description}

Measurements. Males: $\mathrm{L}=32-46.6 \mathrm{~mm}, \mathrm{H}=2.7-3.7 \mathrm{~mm}, 47-50 \mathrm{PR}+1-2 \mathrm{AR}+$ Telson. Female: $\mathrm{L}=$ $53 \mathrm{~mm}, \mathrm{H}=4.6 \mathrm{~mm}, 50 \mathrm{PR}+2 \mathrm{AR}+$ Telson. 

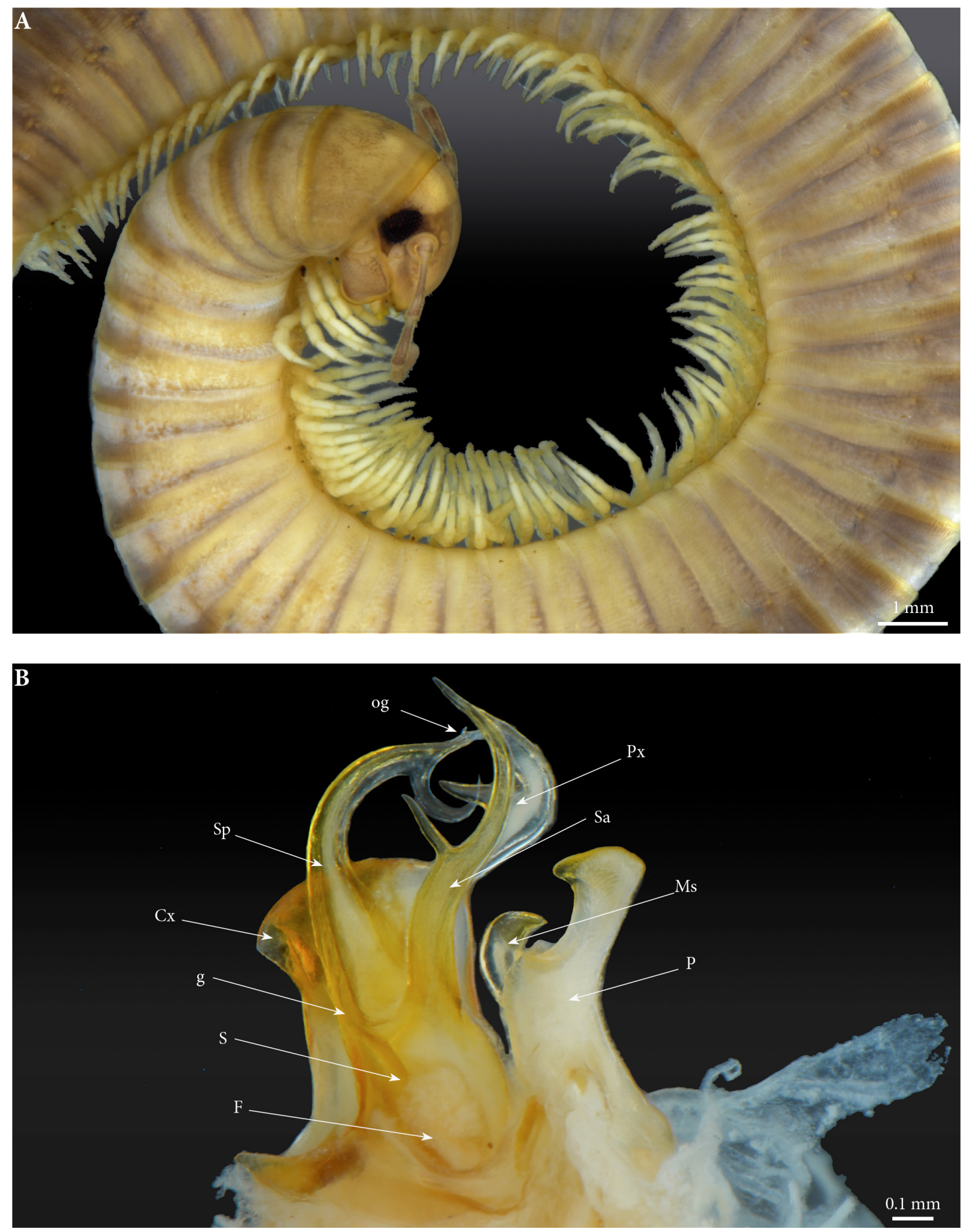

Fig. 19. Ommatoiulus staglae sp. nov. Paratype, $\widehat{\jmath}$. A. Habitus, lateral view. B. Right gonopod, mesal view. 

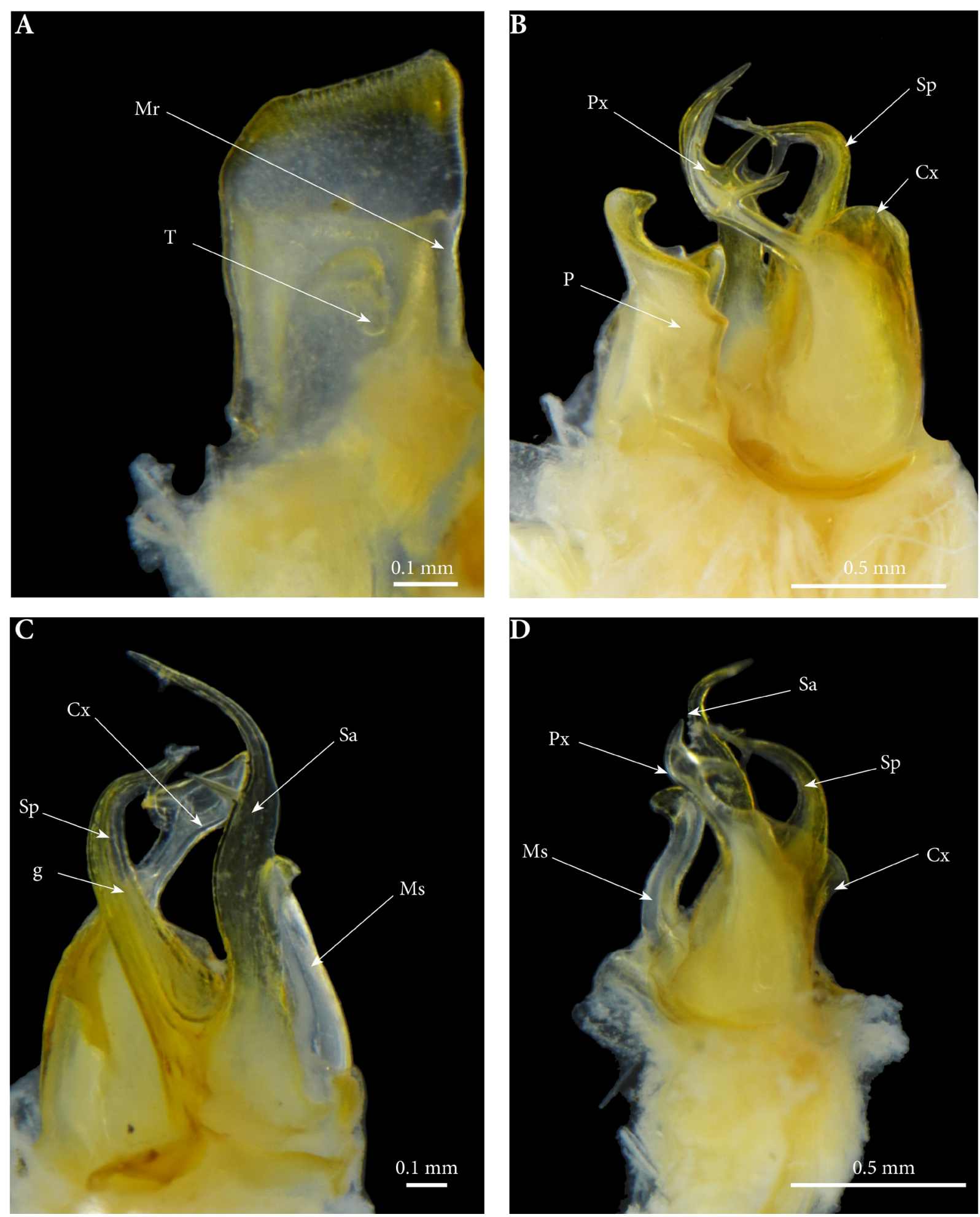

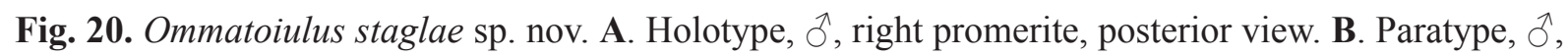

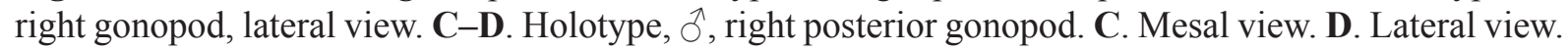


Colour (Fig. 19A). Light brown, faded after 29 years stay in alcohol. Prozonites pale with grey-black sputter, posteriorly forming dorsal triangular spots; metazonites golden brown with a scattered fine black sputter; dorsum with a thin black mid-dorsal line; legs pale brown to yellowish; head light on the epicranium, dark brown on the frontal side, pale towards the labral zone, mouthparts yellowish; telson brownish. Prozonites with oblique striae; metazonites with regular striation; suture complete, rectilinear but sometimes with a sinus at ozopore level. Anal valves with a marginal row of short setae, a submarginal row of longer ones and ca 5-6 setae on the disc. Subanal scale triangular, blunt and setose. Preanal ring with a protruding caudal projection bearing $5+5$ setae and a small hyaline process on the tip.

Gonopods (Figs 19B, 20-21). Promerite (P) in posterior view subrectangular short and broad with an apical broad tooth pointing posteriad; posterior surface biconcave with a conspicuous rounded rudimentary telopodite $(\mathrm{T})$ located close to the mesal ridge (Mr); the latter broad and protruding in a short blunt process ending at mid-length of the promerite and separated from the mesal margin by a big rounded notch (Fig. 19B); lateral margin more or less straight, gently curving distad, apical margin oblique. Mesomerite (Ms) very reduced with a curved, downturned apex, shorter than the promerite and half as long as the anteriormost solenomerite process, bi-sinuous, nesting against the promerite posterior concavities; solenomerite (S) large, with two long and oppositely directed processes: the anterior process (Sa) longest, slightly curved, bearing an accessory branch at $2 / 3^{\text {rd }}$ length, distally gradually tapering into a

A

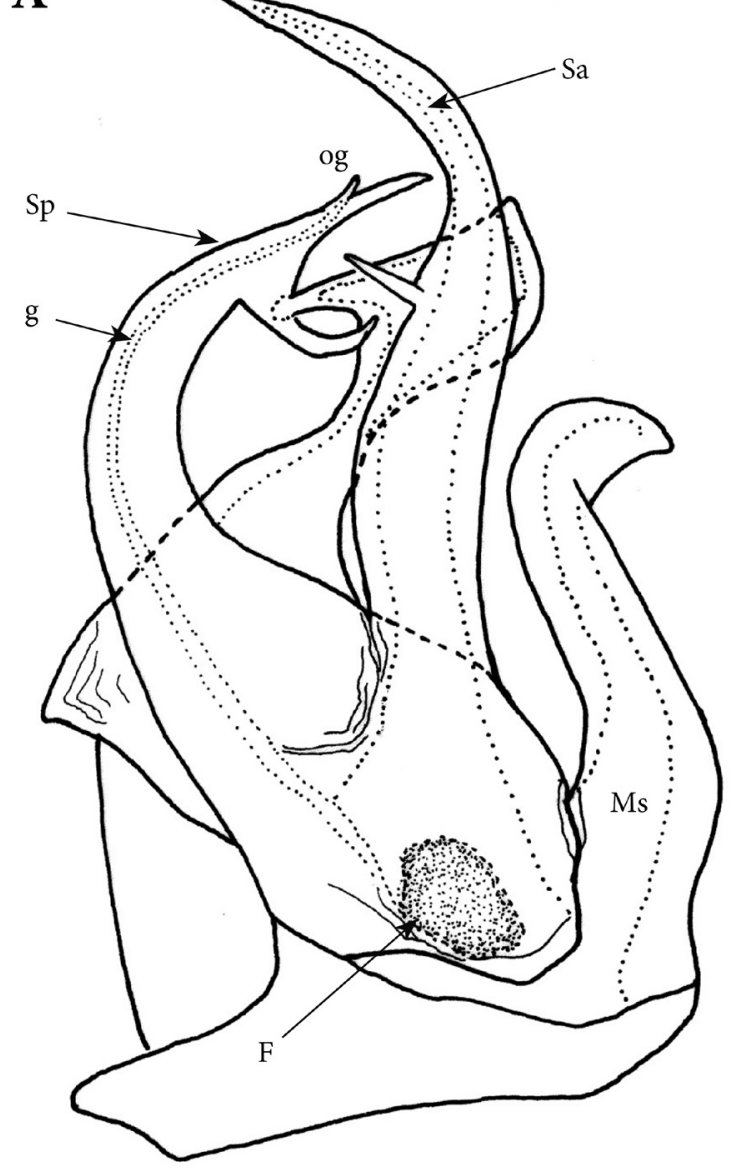

B

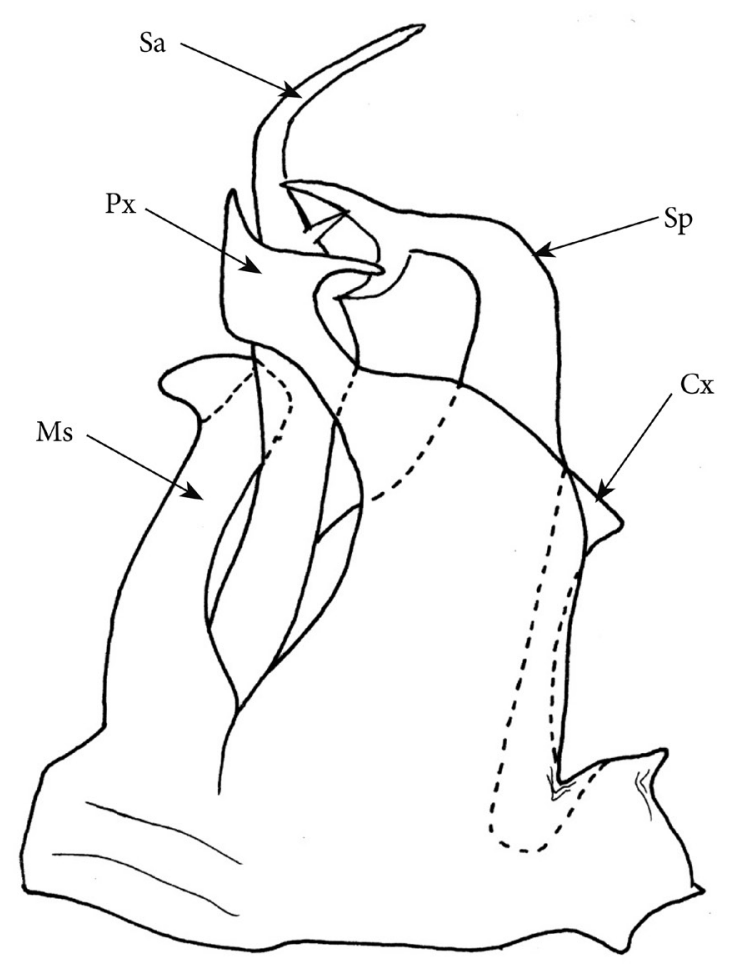

$0.1 \mathrm{~mm}$

$0.1 \mathrm{~mm}$

Fig. 21. Ommatoiulus staglae sp. nov. Holotype ${ }^{\Uparrow}$, right posterior gonopod. A. Mesal view. B. Lateral view. 
thin curved spine directed posteriad, and the posterior process (Sp) gradually narrowing distally, apically abruptly expanding and bifurcating into a 'fish-tail' with two slender short tines. Seminal groove (g) running posteriorly from the fovea (F) (Figs 19B, 21A) located at the base of the solenomerite up to og at the tip of Sp. Paracoxite (Px) narrow, expanded distally and bearing two apical asymmetrical processes pointing posteriad (Figs 20B, 21B). Coxa (Cx) large with a prominent posterior margin protruding in a rounded bulge.

\section{Distribution}

South Portugal, Algarve.

\section{Ommatoiulus stellaris sp. nov. urn:1sid:zoobank.org:act:1A81DFA5-8EE7-494E-8759-A037087F6E6D}

Figs $22-23$

\section{Diagnosis}

One of the smallest species of the genus Ommatoiulus, different from all congeners by the combination of two distinct meso-apical teeth on the promerite, a complex solenomerite with subapical ramifications and a distally expanding mesomerite.

\section{Etymology}

The name is a Latin noun in the genitive, meaning "of the star" and refers to the type locality ('estrela' is Portuguese for 'star').

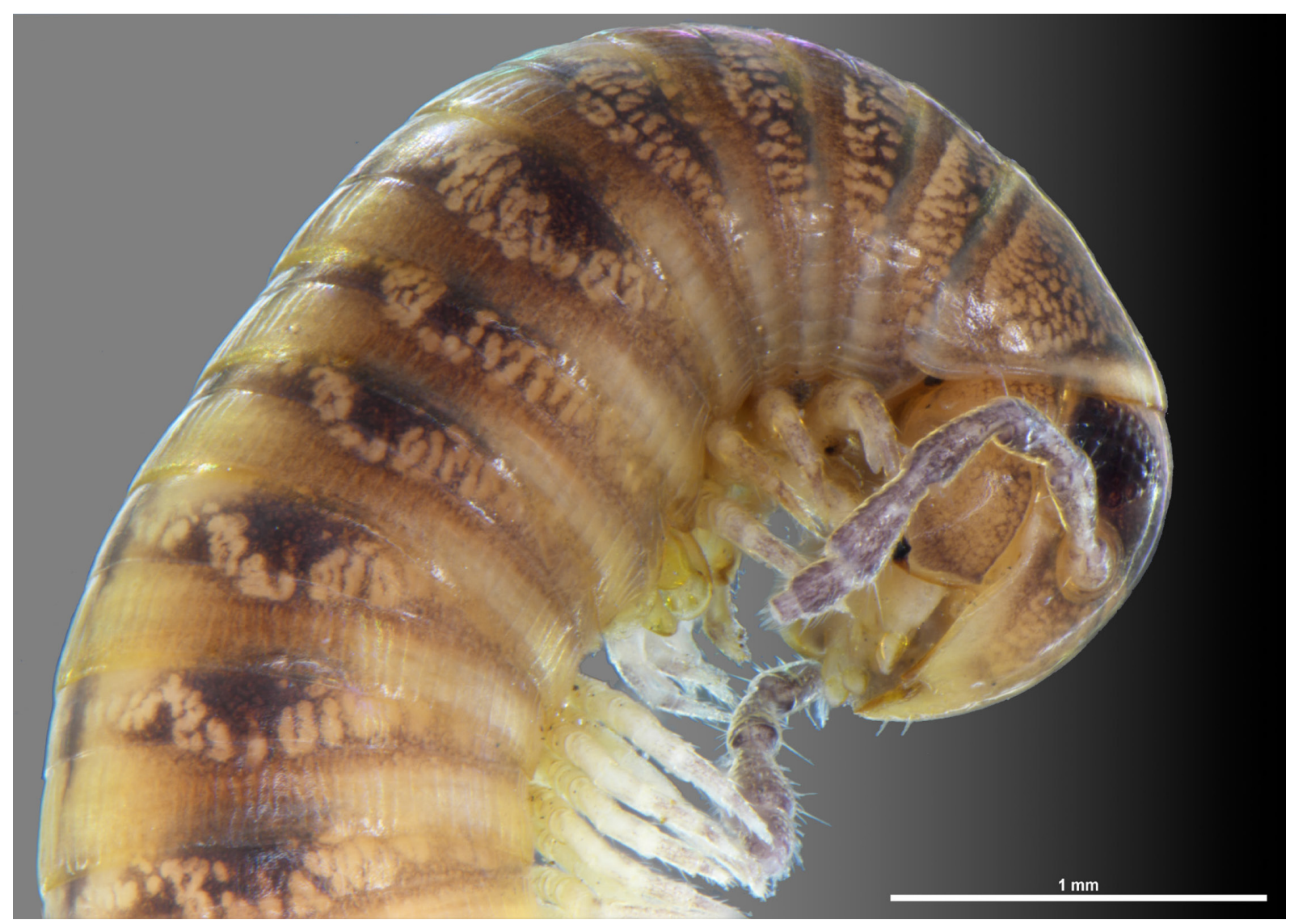

Fig. 22. Ommatoiulus stellaris sp. nov. Paratype $\hat{\jmath}$, head and anteriormost rings. 

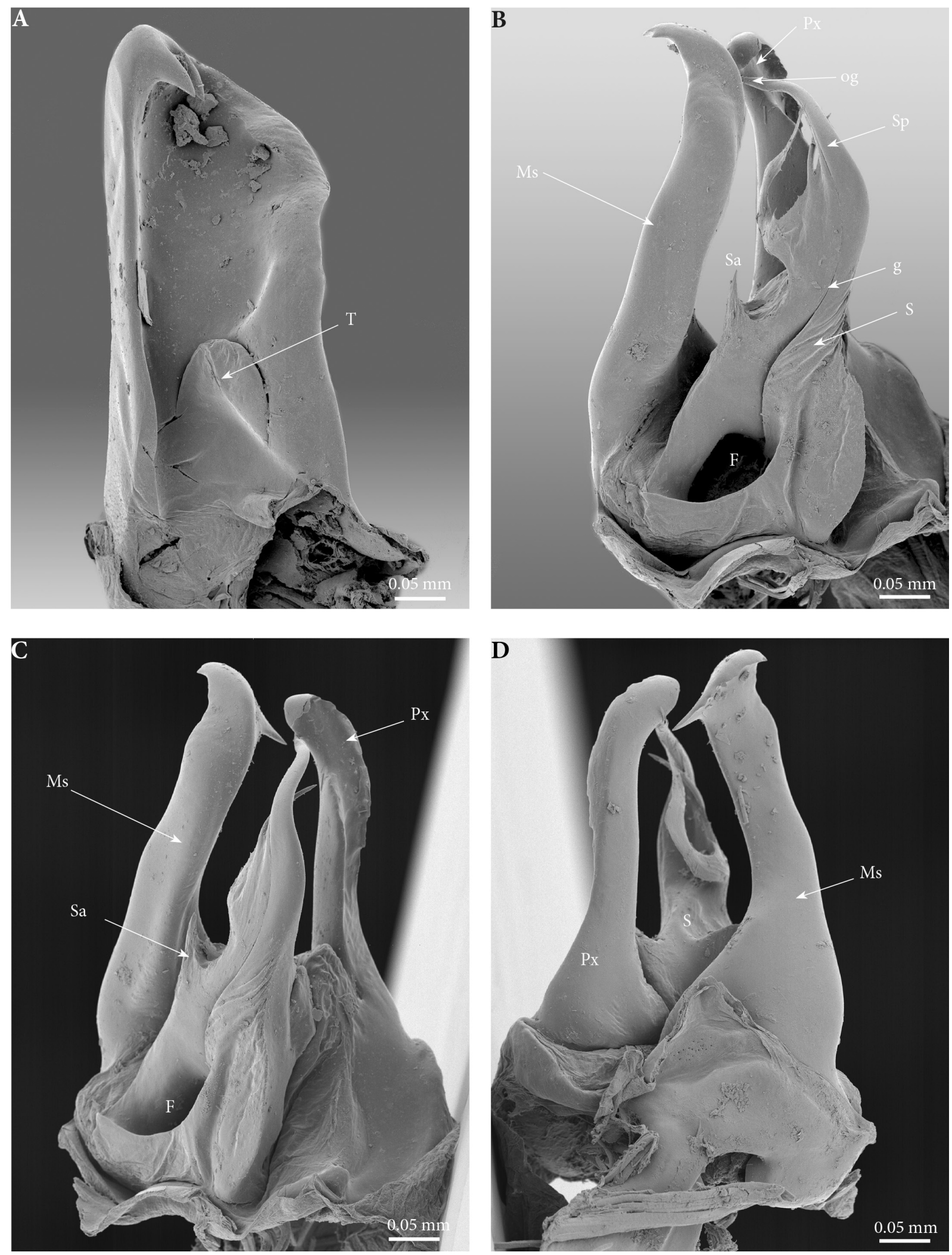

Fig. 23. Ommatoiulus stellaris sp. nov. Paratype $\delta^{\lambda}$. A. Left promerite, posterior view. B. Left posterior gonopod, mesal view. C. Left posterior gonopod, postero-mesal view. D. Left posterior gonopod, anterolateral view. 
AKKARI N. \& ENGHOFF H., The genus Ommatoiulus in Portugal

\section{Material examined}

Holotype

PORTUGAL: 1 đ̊, Serra da Estrela, Torre, alt. 1900 m, 25 Oct. 1996, O. Martin leg. (ZMUC).

\section{Paratypes}

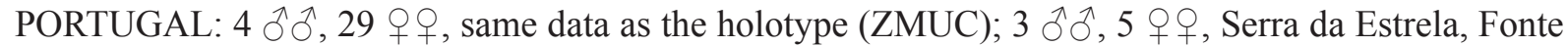
do Perús, pitfall trap, 40.349321 N, 7.626777 W, alt. 1867 m. 5-19 Oct. 2013, Serra da Estrela Project

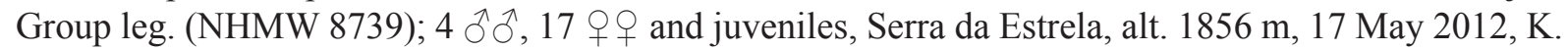
Voigtländer \& H. Reip leg. (SMNG).

\section{Other material studied}

PORTUGAL: $4 \hat{\jmath} \widehat{\partial}, 1$, Serra da Estrela, Lagoa do Covão do Quelhas, pitfall trap, 40.327867 N, 7.626767 W, alt. 1817 m. 35 May-13 Jun. 2013, Serra da Estrela Project Group leg. (Animal Biology Department, Faculty of Sciences, University of Lisbon); 2 수, 3 우우, Serra da Estrela, Lagoa Serrano, small dam, pitfall trap, 40.328283 N, 7.631417 W, alt. 1798 m, 30 May-13 Jun. 2013, Serra da Estrela Project Group leg. (Animal Biology Department, Faculty of Sciences, University of Lisbon); 1 ô, 1 , Serra da Estrela, Lagoa Srrano, small dam, pitfall trap, 40.349321 N, 7.626777 W, alt. 1798 m. 6-23 Oct. 2013, Serra da Estrela Project Group leg. (Animal Biology Department, Faculty of Sciences, University of Lisbon).

\section{Description}

Measurements. Males: $\mathrm{L}=16-34.9 \mathrm{~mm}, \mathrm{H}=1.4-1.7 \mathrm{~mm}, 42-48 \mathrm{PR}+1-3$ AR+Telson. Females: $\mathrm{L}=$ 18.4-37.8, H = 1.7-3.1, 42-51 PR+1-3 AR+Telson.

Colour. Brown, lighter on the lateral sides below the ozopore line and with two pale bands on the dorsum. Prozonites (Fig. 22) with scattered black sputter, becoming dense and discontinued with a round-oval pale spots sub-laterally, dorsum paler with median black spots; metazonites pale and translucent; dorsum with a thin black mid-dorsal line; legs light brown to yellowish; head brown with dense black sputter on the frontal part between the ocelli fields, lighter towards the labral zone, mouthparts yellow, antennae purple-brown, telson light brown to yellowish. Prozonites with oblique striae; metazonites with regular striation; suture complete, rectilinear but sometimes with a sinus at ozopore level. Anal valves with a marginal row of short setae, a submarginal row of ca 10 longer ones and ca 2 setae on the disc. Subanal scale triangular, blunt and setose. Preanal ring with a short triangular caudal projection, bearing a small hyaline process and $2+2$ setae on the lateral sides.

Gonopods (Figs 22B-C, 23). Promerite (P) in posterior view subrectangular with parallel margins until $2 / 3^{\text {rd }}$ length where the lateral margin abruptly expands, bends anteriad, then gently curves towards the apex, the latter with two apical triangular teeth pointing posteriad; mesal ridge (Mr) fairly broad, ending in a blunt process at mid-length of the promerite; rudimentary telopodite $(\mathrm{T})$ conspicuous, located proximally on the posterior surface (Fig. 23A), broad and rounded. Posterior gonopod (Figs 22-23): Mesomerite (Ms) shorter than promerite, with a broad base, gradually narrowing and bent laterad at mid-length (Fig. 23B), distally expanding meso-laterad (Fig. 23D) showing a smooth rounded apex, a serrated subapical margin, with a strong mesal tooth and a lateral downturned triangular process (Fig. 23D); solenomerite (S) large, with one main lamella marked with deep serrated notches and divided in dissimilar processes separating at different level and with a posterior serrated margin (Fig. 23B) and an anterior reduced process $(\mathrm{Sa})$ short and pointing distad; the lamella distally shows a thin process curved antero-laterad and gently tapering into an acuminate tip pointing distad; a thin process with an acuminate tip and pointing posteriad and a slightly broader posterior process $(\mathrm{Sp})$ lodging the opening of the seminal groove 'og', the groove (g) running posteriorly from the fovea (F) located at the base of the 
solenomerite up to og (Fig. 23B). Paracoxite (Px) stout, uniformly broad, mesal margin with a rounded projection at mid-length, apically rounded with a downturned serrated margin.

\section{Distribution}

Only know from high altitudes, $1798-1867 \mathrm{~m}$ in the Serra da Estrela Mountain massive, Portugal.

\section{Checklist of Ommatoiulus species in Portugal}

Ommatoiulus alacygni sp. nov.

Ommatoiulus andalusius (Attems, 1927), new record

Ommatoiulus bipartitus (Verhoeff, 1925)

Ommatoiulus camurus sp. nov.

Ommatoiulus denticulatus sp. nov.

Ommatoiulus dorsovittatus (Verhoeff, 1893)

Ommatoiulus fuentei (Brolemann, 1920), new record

Ommatoiulus litoralis sp. nov.

Ommaoiulus lusitanus (Verhoeff, 1895)

Ommatoiulus martensi Mauriès, 1969, new record

Ommatoiulus moreleti (Lucas, 1860)

Ommatoiulus oliveirae (Verhoeff, 1893)

Ommatoiulus porathi (Verhoeff, 1893)

Ommatoiulus staglae sp. nov.

Ommatoiulus stellaris sp. nov.

Identification Key to the Portuguese species of Ommatoiulus based on gonopod structures

1. Paracoxite deeply divided into 2 processes (Fig. 15D) .......................... O. lusitanus (Verhoeff, 1895)

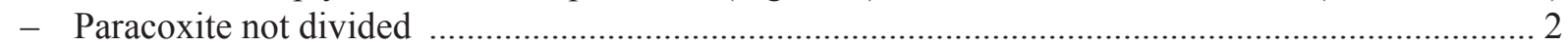

2. Mesomerite reduced, almost half as long as the promerite (Figs 2C, D, 9D, 19B) ........................ 3

- Mesomerite normal to large - sometimes extending beyond the rest of processes (Figs 7A, 13A) . 5

3. Coxa or paracoxite with strong serrations (Figs 2D, 9D); promerite distally narrowed in a rounded apex; solenomerite with hyaline lamella (Figs 2E, C, 10)....

- Coxa and paracoxite with no conspicuous serrations; promerite uniformly broad; solenomerite without hyaline lamella (Fig. 18). .o. staglae sp. nov.

4. Paracoxite distally expanded, leaf-shaped, and bearing strong serrations on the lateral margin (Figs 9D, F, 10B); coxa smooth and rounded; solenomerite with one accessory process

O. denticulatus sp. nov.

- Paracoxite distally narrowing, apically with a bulge followed by a pointed tip (Figs 2C, E, 3B), without serrations; coxa 'swan wing-shaped' with 3 blunt processes (Figs $2 \mathrm{C}-\mathrm{D}, 3 \mathrm{C}$ ); solenomerite with 2 accessory processes (Fig. 3C).

O. alacygni sp. nov.

5. Mesomerite shorter than promerite (e.g., Fig. 18D); solenomerite with a broad lamella bearing notches and distal ramifications (e.g., Fig. 18B)

- Mesomerite as long as the promerite, sometimes extending beyond the rest of processes (e.g., Figs 13A, 24A), solenomerite different, large species. 
6. Promerite with two postero-apical teeth, solenomerite with 3 notches and 4 slender to acuminate ramifications (Fig. 23B), mesomerite distally expanded mesolaterad (Fig. 23D).

O. stellaris sp. nov.

- Promerite with one or no apical teeth, solenomerite with one notch and one distal ramification, mesomerite uniformly broad, distally narrowing and curved (Figs 4C, 18B).

7. Promerite with a strong apical tooth, solenomerite long and broad, distally narrower, with a subapical curved acuminate process and an apical subtriangular fold (Fig. 4C).

O. andalusius (Attems, 1927)

- Promerite with no apical teeth (Fig. 18D), solenomerite short and broad, with two acuminate asymmetrical processes separated by a lamellar fold (Fig. 18B)

O. porathi (Verhoeff, 1893)

8. Mesomerite strongly expanded into a large distal plate with spines and serrations, solenomerite simple (Fig. 24A).

O. martensi Mauriès, 1969

- Mesomerite distally narrowing or bifurcating, solenomerite complex...

9. Solenomerite divided into 3 processes (a large anterior one, a median hyaline fold and an acuminate posterior one); paracoxite broad, distally expanding (Fig. 5B-C)

- Solenomerite more complex, heavily serrated, with a furrow and other accessory branches (Fig. 8B); paracoxite slender or completely reduced (Fig. 8C)..... 12

10. Mesomerite with apical projections, paracoxite expanded, with several distal projections .11

- Mesomerite without apical projections (Fig. 14A), paracoxite hammer-shaped (Fig. 14B)

O. litoralis sp. nov.

11. Promerite with an apical incision and a protruding mesal margin; paracoxite strongly curved

O. bipartitus (Verhoeff, 1925) (Fig. 24B)

- Promerite with a regular margin and no apical incision O. moreleti (Lucas, 1860) (Fig. 24C)

12. Mesomerite distally not bifurcated; paracoxite long slender and curved (Fig. 24E)

O. fuentei (Brolemann, 1920)

- Mesomerite distally bifurcated; paracoxite short to very reduced (Figs 7D, 17B, 24D)

13. Promerite strongly narrowed distally (Figs 7B, 8A), apex with a serrated mesal fold and a pointed lateral margin; mesomerite curved from basis and pointing mesad, both apical processes pointing in the same direction (Figs 7A, D, 8B)....

O. camurus sp. nov.

- Promerite gently narrowed distally, apex with regular margins (Figs 17A, C, 24D); mesomerite curved from distal third, mainly pointing laterad (Figs 17B, D, 24D)... 14

14. Paracoxitevery reduced with transversal stripes, mesomerite distally withalong curved process pointing laterad and a much shorter one pointing posteriad (Fig. 24D) ...... O. dorsovittatus (Verhoeff, 1893)

- Paracoxite longer, mesomerite apically with subequal ramifications oppositely directed (Fig. 17B, D) O. oliveirae (Verhoeff, 1893)

\section{Discussion}

Fifteen Ommatoiulus species are here recorded for Portugal among which six are new to science. In all species we described, the males share the secondary sexual characters consisting in the presence of mandibular stipes vertically expanded into rounded lobes; hook-shaped first pair of legs (Fig. 25) and the presence of postfemoral and tibial pads on subsequent legs. 


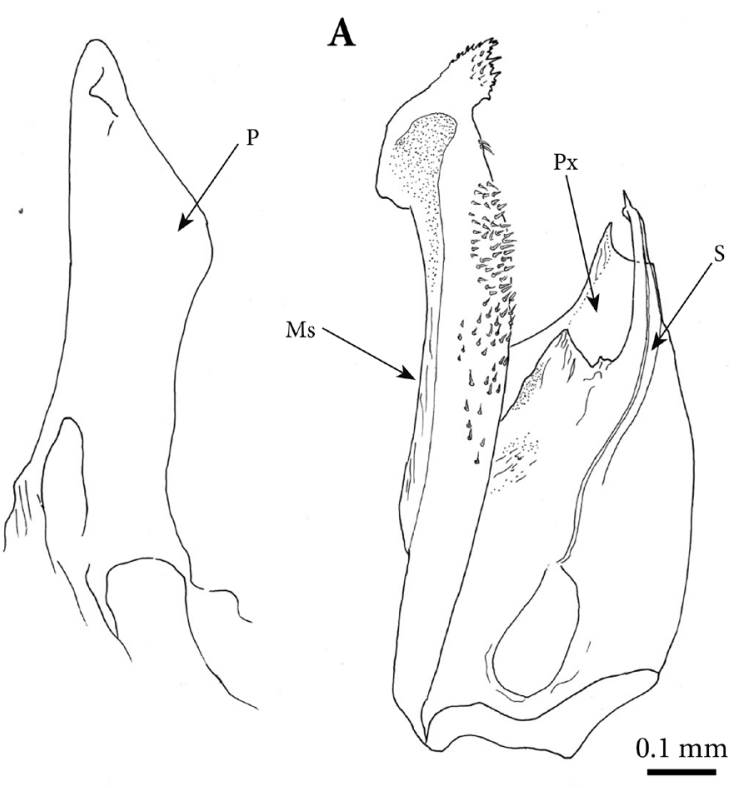

C
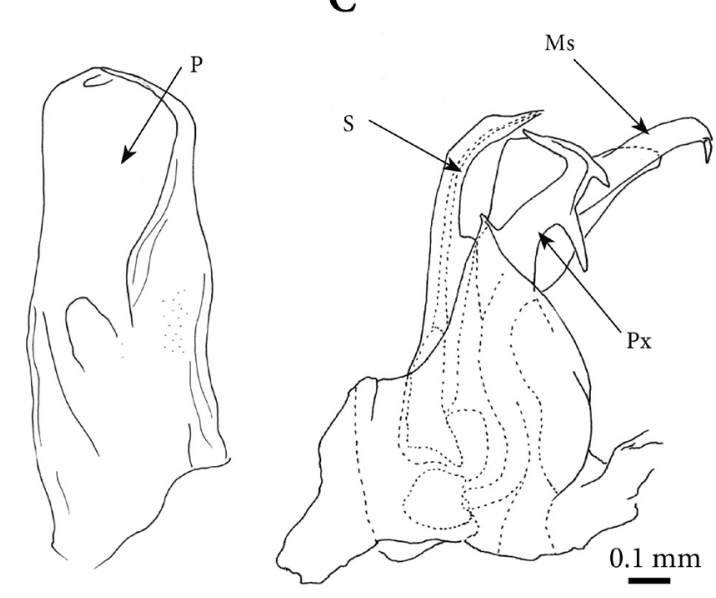
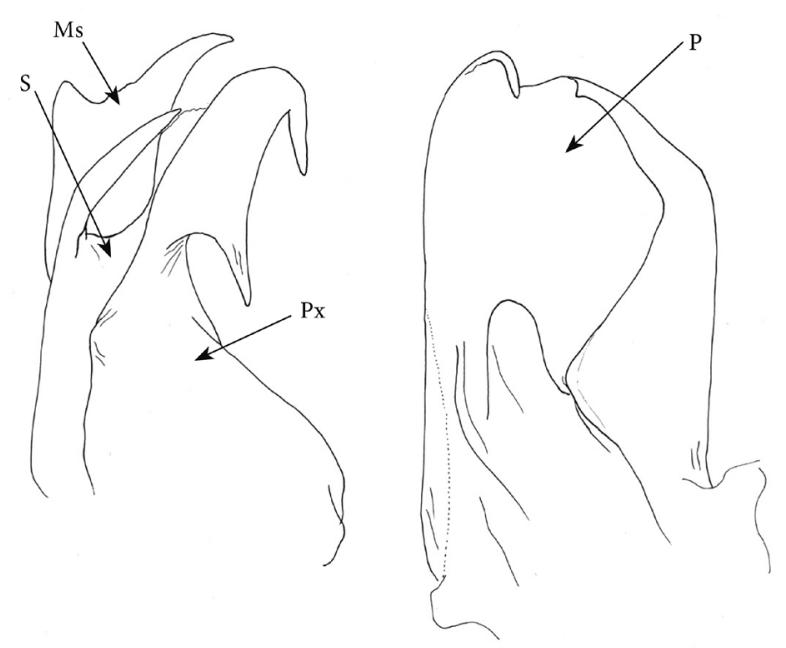

$\underline{0.1 \mathrm{~mm}}$

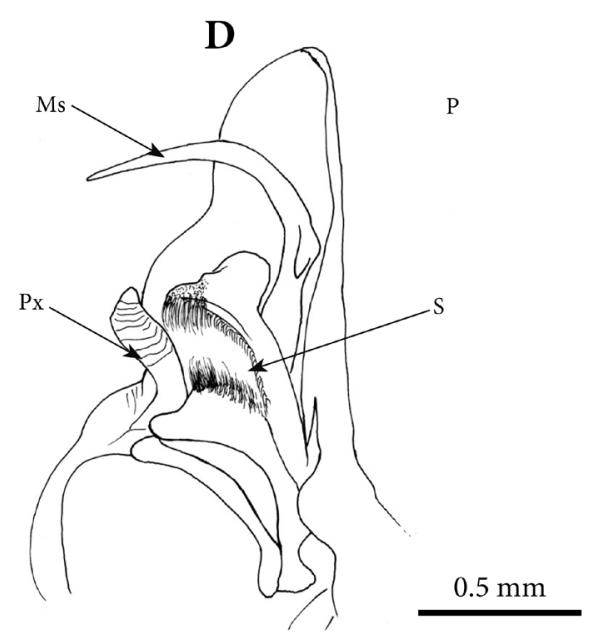

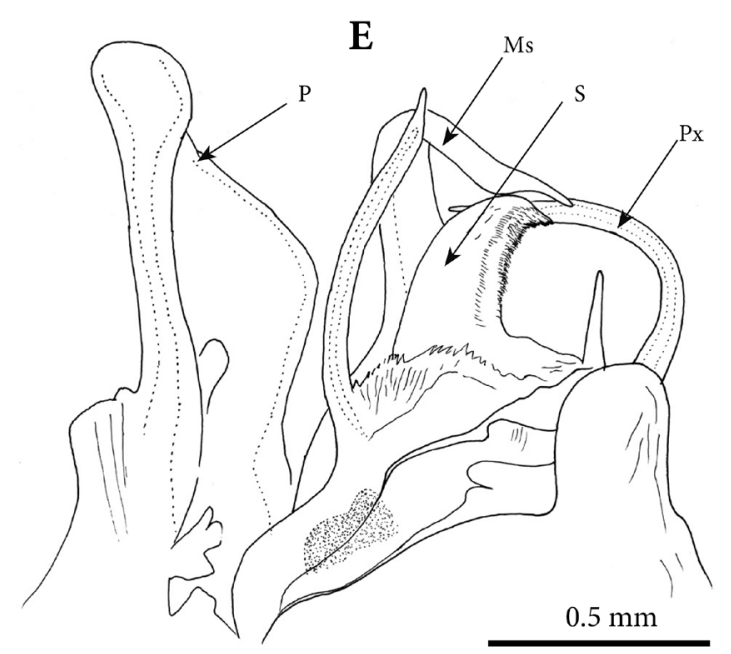

Fig. 24. A. Ommatoiulus martensi Mauriès, 1969, left gonopods. B. O. bipartitus (Verhoeff, 1925), left gonopods. C. O. moreleti (Lucas, 1860), left gonopods. D. O. dorsovittatus (Verhoeff, 1893), right gonopods. E. O. fuentei (Brolemann, 1920), left gonopods. 
The species $O$. andalusius, $O$. fuente $i$ and $O$. martensi are recorded for the first time in Portugal whereas $O$. andalusius and $O$. porathi are documented for the first time after their original descriptions. Though it is one of the most widely distributed millipede species in Europe, we exclude $O$. sabulosus from the Portuguese list of species [recorded from Bragança Province, Moncorvo, Serra do Reboredo by Machado (1946)] as the record was not accompanied by any descriptive notes or illustrations, and confusion with another species seems likely.
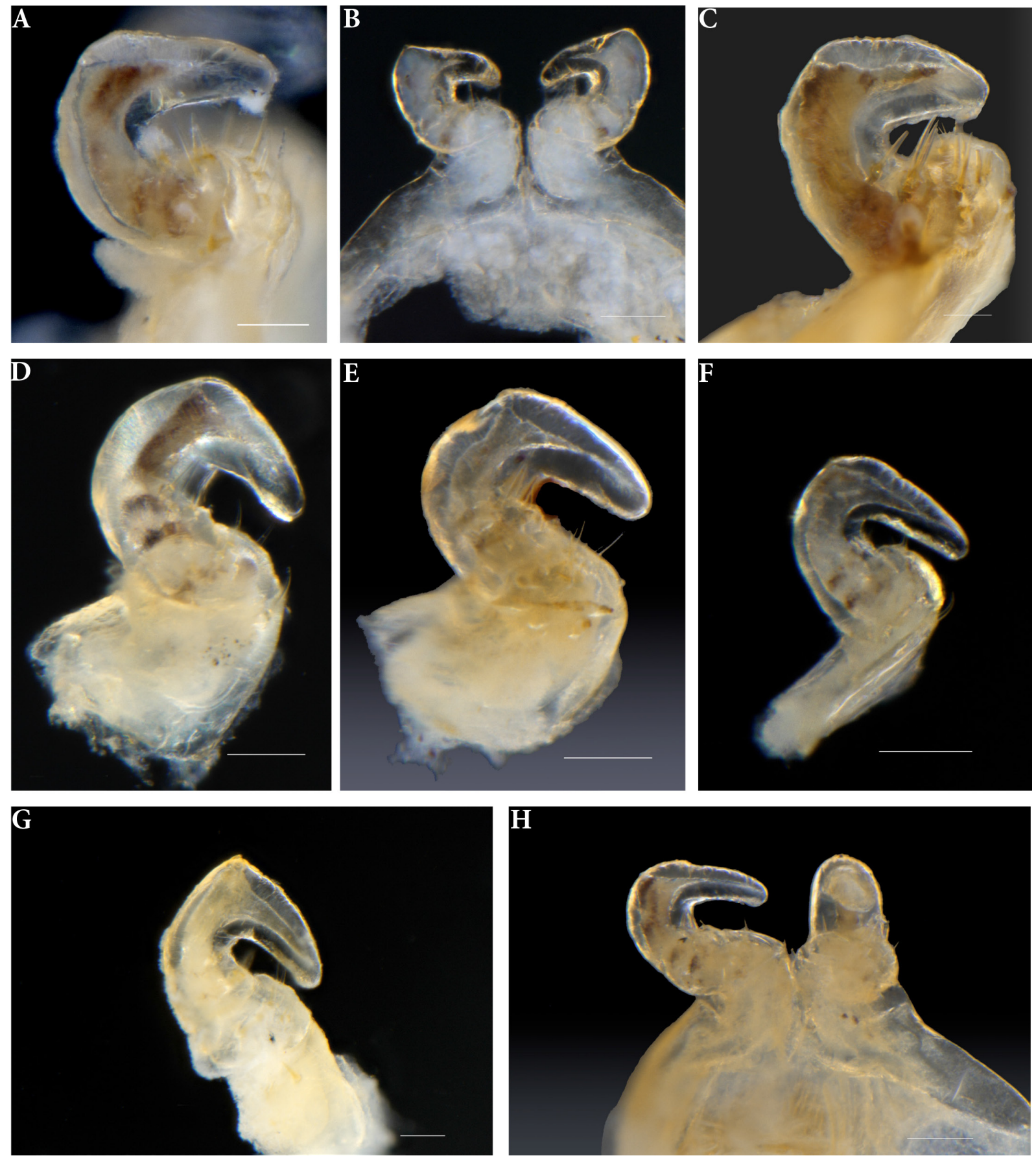

Fig. 25. First leg pair. A. Ommatoiulus alacygni sp. nov. B. O. andalusius (Attems, 1927). C. O. camurus sp. nov. D. O. denticulatus sp. nov. E. O. litoralis sp. nov. F. O. porathi (Verhoeff, 1893). G. O. staglae sp. nov.. H. O. stellaris sp. nov. Scale bars $0.1 \mathrm{~mm}$. 
Based on new records and comparison of type material, O. cingulatus and $O$. cervinus are here considered as junior synonyms of $O$. lusitanus and $O$. moreleti, respectively. However, the taxonomy of a few other species treated here is still not entirely clear and require further morphological and molecular investigation. The moreleti-group (subgenus Hemipodoiulus sensu Verhoeff 1892) in particular remains only partly clarified. O. moreleti itself is highly diverse, as documented by Attems (1928), Baker (1984) and Schubart (1966) who shed light on a few morphotypes. Among the morphotypes noted by Baker (1984), we suspect that the type D from Braga (northern Portugal) actually belongs to the O. bipartitus complex, while the type $\mathrm{C}$ from Coimbra largely agrees with some Spanish specimens we examined from Madrid and Avilà (unpublished data). Morphological variation was not only observed in $O$. moreleti but also in the other species from the group. Whether Schizophyllum involutum, long considered as synonymous with O. bipartitus (Mauriès \& Vicente 1977), should be resurrected remains an open question as specimens perfectly matching Verhoeff's (1925) description and showing the characteristic shape of promerite and paracoxite have been found again in Oporto and in Braga, type locality of $S$. involutum but have also been identified from A Coruña in Galicia (unpublished), type locality of O. bipartitus.

Ommatoiulus bipartitus has, on the other hand, also been identified from northern Spain in Asturias and Leon (unpublished records) (Fig. 5A), whereas $O$. lienharti, now also regarded as a synonym of O. bipartitus, and described from Arcachon (SW France) has further been identified from Álava, Cantabria and the Basque Country. The lienharti and involutus morphotypes agree in the shape of the promerite (devoid of the apical projection) and a less curvy aspect of the apex of the paracoxite, typical of $O$. bipartitus. The lienharti and involutus morphotypes both exhibit a larger number of distal processes and teeth on the paracoxite than typical O. bipartitus. Whereas the typical bipartitus is confined to Galicia, the involutus and lienharti morphotypes have a wider distribution stretching from the French Pyrenees to Portugal. During our study, we observed also other morphs, for example the one from the Basque Country (Fig. 5D) and which we could not assign with certainty to any of the already mentioned ones. Thus we believe that only a detailed combined molecular and morphological study will elucidate the taxonomic status of these morphotypes/species and their phylogenetic relationships.

In a previous treatment of the genus Ommatoiulus (Akkari \& Enghoff 2012), we defined some informal species groups A, B and C for the Andalusian species. The Portuguese species $O$. oliveirae, O. dorsovittatus and $O$. camurus sp. nov. perfectly agree with species group B which potentially coincides with the Elaphophyllum Verhoeff, 1921/Eleutheroiulus Attems, 1894 subgeneric division although O. camurus sp. nov. remains quite remarkable with the curvature of the mesomerite as well the shape of the coxa.

The species $O$. porathi might form an additional species group D together with $O$. sabulosus. This group is characterised by: 1) a promerite with a rounded apex, bearing no incision and gently narrowing distad; 2) a slender mesomerite; 3 ) a solenomerite with a distal lamella and a longer mesal projection; 4) a stout paracoxite.

The species, $O$. andalusius, $O$. stellaris sp. nov. and $O$. porathi are - together with the Spanish species O. parvus (Brolemann, 1920) - the smallest known species of genus Ommatoiulus (body diameter less than $1.7 \mathrm{~mm}$ in males). O. stellaris sp. nov. is also notable by the presence of two distinct and strong apical teeth on the promerite, a structure similar to that seen in some Pachyiulini including the genus Dolichoiulus Verhoeff, 1900 (Enghoff 1992) although the rest of the features of the promerite are completely Ommatoiulus-like while Dolichoiulus traits of the promerite like spoon-shape, protruding lateral margin, and mesal ridge, are absent.

The Ommatoiulus fauna of the Algarve region (see Fig. 26) comprises 3 new species, viz. Ommatoiulus alacygni sp. nov., $O$. denticulatus sp. nov. and $O$. staglae sp. nov. all characterized by a remarkably 
reduced mesomerite, a complex solenomerite and a large paracoxite. They might form an additional species group E. In $O$. staglae sp. nov. and $O$. denticulatus sp. nov., the posteriormost gonopod process shows further spectacular modifications, being strongly contorted and bearing big serrations on the paracoxite margin as in denticulatus or a strongly prominent and serrated coxa as in $O$. alacygni sp. nov. The reduced mesomerites are particularly interesting from an evolutionary point of view. A mesomerite ( $=$ an anterior, more or less separate process originating from the posterior gonopod) is regarded as an important evolutionary innovation in the family Julidae (Read 1990, see also Enghoff et al. 2011). Together with the promerite, the mesomerite in most cases forms a pair of forceps which have been shown to grab the operculum of the female's vulva during copulation (Haacker \& Fuchs 1970, Tadler 1996). In Ommatoiulus the mesomerite may take numerous highly different shapes, and it is not always obvious that the forceps function has been retained. In the closely related 'genus' Rossiulus, the mesomerite is strongly reduced, a condition paralleled in Ommatoiulus group E. A comparative study on the copulatory mechanisms of Ommatoiulus species with differently modified/reduced mesomerites would probably be quite rewarding.
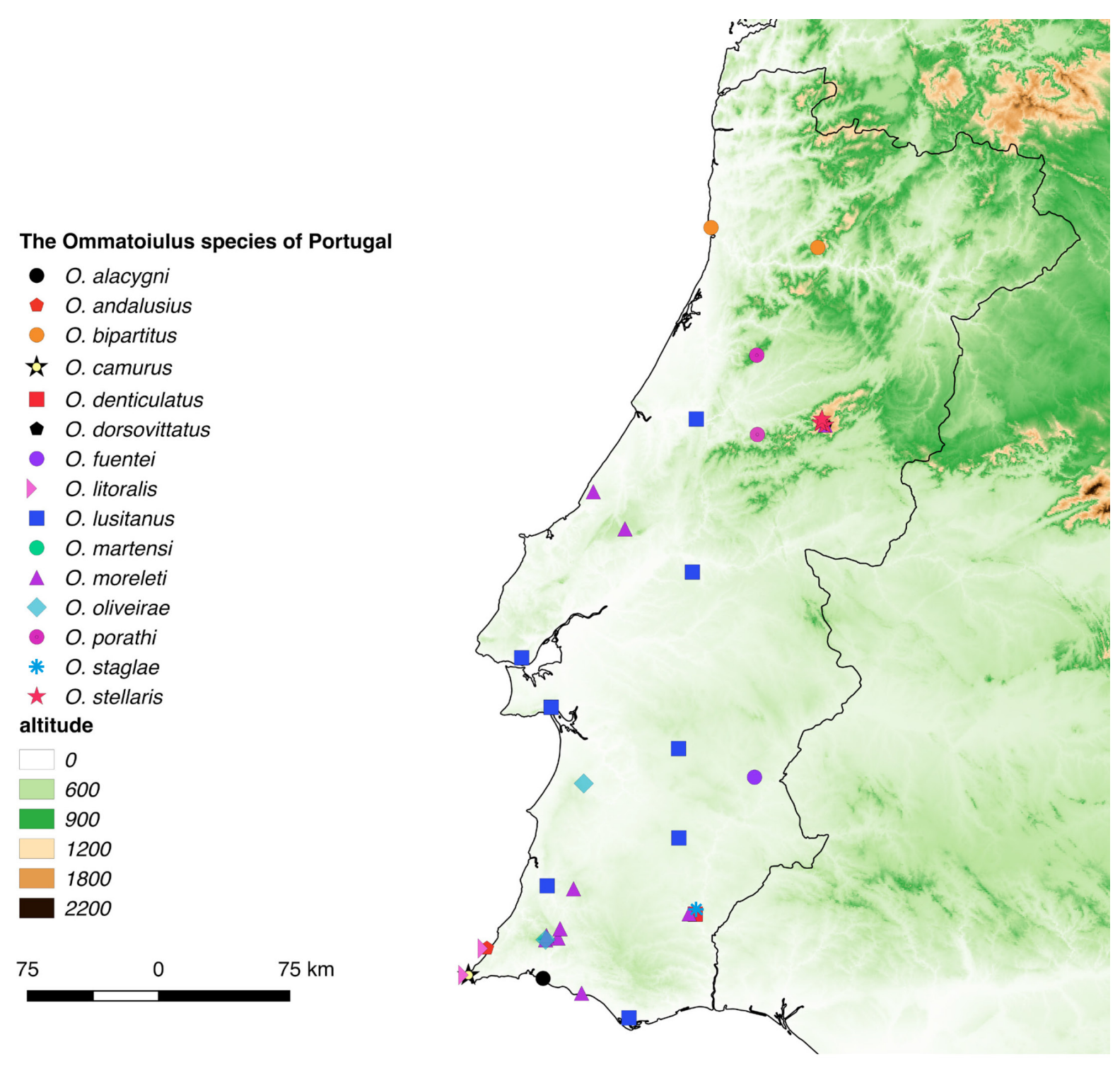

Fig. 26. Distribution map of Ommatoiulus species in Portugal. 


\section{Acknowledgements}

This work would not have been possible without several people who contributed in various ways. We are most grateful to Carlos Aguiar, Desmond Kime, Ernesto Recuero, Hans Reip, Karin Voigtländer, Mario Garcia París, Ole Martin, Pedro Cardoso and Peter Bailey for collecting and providing valuable specimens for this study. Our gratitude is also extended to the following persons for arranging loans under their care and/or giving access to type material and important information and/or support during the visits of N. Akkari to their respective institutions: Jason Dunlop (ZMB), Jean-Jacques Geoffroy and Jean-Paul Mauriès (MNHN), Karin Voigtländer (SMNG), Roberta Salmaso (MCSNV), and Marian Ramos (MNCN).

This work was partly financed by Synthesys DK-TAF 4455 allocated to N. Akkari, who is also grateful to Nana Manniche for her friendly and efficient help during her visit to Copenhagen in April 2015 and to Edmund Schiller (NHMW) for his devoted support. We are most obliged to Dragan Antić (University of Belgrade) and an anonymous reviewer for their valuable comments and corrections.

\section{References}

Akkari N. \& Enghoff H. 2012. Review of the genus Ommatoiulus in Andalusia, Spain (Diplopoda: Julida) with description of ten new species and notes on a remarkable gonopod structure, the fovea. Zootaxa 3538: 1-53.

Attems C. 1927. Myriopoden aus dem nördlichen und östlichen Spanien, gesammelt von Dr. F. Haas in den Jahren 1914-1919. Nebst Beiträgen zur Kenntnis der Lithobiiden, Glomeriden sowie der Gattungen Brachydesmus und Archiulus. Abhandlungen der Senckenbergischen naturforschenden Gesellschaft 39 (3): 233-289.

Attems C. 1928. The Myriapoda of South Africa. Annals of the South African Museum 26: 1-431.

Bailey P.T. \& De Mendonça T.R. 1990. The distribution of the millipede Ommatoiulus moreleti (Diplopoda, Julida, Julidae) in relation to other Ommatoiulus species on the south-western Iberian Peninsula. Journal of Zoology 221 (1): 99-111.

Baker G.H. 1984. Distribution, morphology and life history of the millipede Ommatoiulus moreletii (Diplopoda: Iulidae) in Portugal and comparisons with Australian populations. Australian Journal of Zoology 32 (6): 811-822.

Berlese A. 1886. Julidi del Museo di Firenze - Contributo alla fauna miriapodologica Italiana [Part 1]. Bollettino della Società entomologica Italiana 18: 42-96.

Brolemann H.W. 1920. Myriapodes recueillis par D. J.-M. de la Fuente. Memorias de la Real Sociedad Española de Historia Natural 11 (4): 125-147.

Brolemann H.W. 1921. Description d'une race française de Schizophyllum moreleti (Lucas) et d'une anomalie d'un male de la race typique. Bulletin de la Société d'Histoire naturelle de Toulouse 49: $182-195$.

Enghoff H. 1992. Dolichoiulus - a mostly Macaronesian multitude of millipedes. With the description of a related new genus from Tenerife, Canary Islands (Diplopoda, Julida, Julidae). Entomologica Scandinavica Supplement (40): 1-158.

Enghoff H., Petersen G. \& Seberg O. 2011. Phylogenetic relationships in the millipede family Julidae. Cladistics 27: 606-616. https://doi.org/10.1111/j.1096-0031.2011.00360.x

Haacker U. \& Fuchs S. 1970. Das Paarungsverhalten von Cylindroiulus punctatus Leach. Zeitschrift für Tierpsychologie 27: 641-648. 
Hoffman R. 1980 [for 1979]. Classification of the Diplopoda. Muséum d'Histoire naturelle, Genève.

Machado A. 1946. Contribuição para o conhecimento dos Miriápodes de Portugal. Broteria Ciencias Naturais 15: 5-37.

Machado A. 1953. Alguns miriapodes des Espanha. Archivos Instituto Aclimaticion 1: 77-92.

Mauriès J.-P. 1969. Description de deux espèces nouvelles du genre Ommatoiulus (Latzel) (Schizophyllum Verhoeff, 1895) récoltées dans les Pyrénées Occidentales et les Monts Cantabriques (Diplopoda, Julidae). Bulletin de la Société d'histoire naturelle de Toulouse 105: 329-336.

Mauriès J.-P. 1971. Diplopodes épigés et cavernicoles des pyrénées espagnoles et des monts cantabriques. IV-V. Blaniulides et Iulides. Bulletin de la Société d'Histoire naturelle de Toulouse 107: 103-116.

Mauriès J.-P. 1978. Myriapodes - Diplopodes du sud de l'Espagne. Annalen des Naturhistorischen Museums in Wien 81: 575-588.

Mauriès J.-P. \& Vicente M.C. 1977. Myriapodes Diplopodes nouveaux ou peu connus des Pyrénées espagnoles, des monts Cantabriques et de Galice. Bulletin du Muséum national d'Histoire naturelle, $3^{e}$ série, Zoologie 315 (452): 529-546.

Read H.J. 1990. The generic composition and relationships of the Cylindroiulini - a cladistic analysis Diplopoda, Julida: Julidae). Entomologica Scandinavica 21: 97-112.

Schubart O. 1966. Diplopoda III: Pselaphognatha, Opisthospermophora, Colobognatha. South African Animal Life 12: 9-227.

Tadler A. 1996. Functional morphology of genitalia of four species of julidan millipedes (Diplopoda: Nemasomatidae; Julidae). Zoological Journal of the Linnean Society 118: 83-97. https://doi. org/10.1111/j.1096-3642.1996.tb01263.x

Verhoeff K.W. 1892. Neue Diplopoden der paläarktischen Region. Zoologischer Anzeiger 15 (403): 377-387.

Verhoeff K.W. 1893a. Vorläufige Mittheilung über neue Schaltstadiumbeobachtungen bei Juliden, eine neue Gruppierung der alten Gattung Julus und einige neue und seltene Diplopoden aus Tirol. Zoologischer Anzeiger 16 (436): 479-482.

Verhoeff K.W. 1893b. Neue Diplopoden der portugiesischen Fauna. Zoologischer Anzeiger 16 (418): $156-159$.

Verhoeff K.W. 1894. Beiträgen zur Anatomie und Systematik der Juliden. Verhandlungen der Zoologischbotanischen Gesellschaft in Wien 44: 137-162.

Verhoeff K.W. 1895. Bemerkungen zu einer "Supplementary Note" des Herrn R. J. Pocock. Archiv für Naturgeschichte 61 (1): 357-361.

Verhoeff K.W. 1910. Über Diplopoden. 11.-15. (31.-35.) Aufsatz: Beiträge zur Kenntnis der Glomeriden, Juliden, Ascospermorpha und Lysiopetaliden, sowie zur Fauna Siziliens, Untersuchungen über Artund Gruppensystematik; Morphologie, nachembryonale Entwicklung; Biologie und Geographie. Nova Acta. Abhandlungen der Kasiserl. Leop.-Carol. Deutschen Akademie der Naturforscher 92 (2): 139448.

Verhoeff K.W. 1921. Chilognathen-Studien (91. Diplopoden-Aufsatz). Archiv für Naturgeschichte 86 A (12): 23-80.

Verhoeff K.W. 1925. Neue Diplopoden-Beiträge. 95. Diplopoden-Aufsatz. Zoologische Jahrbücher, Abteilung für Systematik, Ökologie und Geographie der Tiere 50: 61-122. 
Vicente M.C. 1985. Diplópodos epigeos de Cataluña, II (Julidos). EOS, Revista Española de Entomología 61: 321-350.

Manuscript received: 31 May 2016

Manuscript accepted: 16 July 2016

Published on: 9 March 2017

Topic editor: Rudy Jocqué

Desk editors: Laurence Bénichou and Kristiaan Hoedemakers

Printed versions of all papers are also deposited in the libraries of the institutes that are members of the EJT consortium: Muséum national d'Histoire naturelle, Paris, France; Botanic Garden Meise, Belgium; Royal Museum for Central Africa, Tervuren, Belgium; Natural History Museum, London, United Kingdom; Royal Belgian Institute of Natural Sciences, Brussels, Belgium; Natural History Museum of Denmark, Copenhagen, Denmark; Naturalis Biodiversity Center, Leiden, the Netherlands. 